\title{
Metagenomic Analysis for Taxonomic and Functional Potential of Polyaromatic Hydrocarbons (PAHs) and Polychlorinated Biphenyl (PCB) Degrading Bacterial Communities in Steel Industrial Soil
}

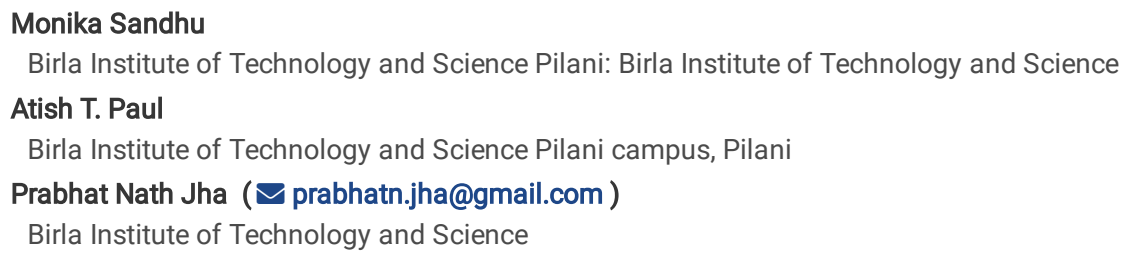

Research Article

Keywords: Metagenomic, Persistant organic pollutants, Biodegradation, Microbial community

Posted Date: June 17th, 2021

DOI: https://doi.org/10.21203/rs.3.rs-564700/v1

License: (c) (i) This work is licensed under a Creative Commons Attribution 4.0 International License. Read Full License 


\section{Abstract}

Iron and steel industries are the major contributors to persistent organic pollutants (POPs). The microbial community present at such sites has potential to remediate these contaminants. The present study highlights the metabolic potential of resident microbial community of PAHs and PCB contaminated soil nearby Bhilai steel plant, Chhattisgarh (India). The GC-MS/MS analysis of soil samples MGB-2 (sludge) and MGB-3 (dry soil) resulted in identification of different classes of POPs including PAHs \{benzo[a]anthracene (nd; 17.69\%), fluorene (15.89\%, nd), pyrene (nd; 18.7\%), benzo(b)fluoranthene (3.03\%, nd), benzo(k)fluoranthene (11.29\%; nd), perylene (5.23\%; nd)\} and PCBs (PCB-15, PCB-95, and PCB-136). Whole-genome metagenomic analysis by Oxford Nanopore GridION Technology revealed Proteobacteria (44.3\%; $50.0 \%$ ) to be the prominent phylum followed by Actinobacteria (22.1\%; $19.5 \%$ ) in MBG-2 and MBG-3, respectively. The sample MGB-3 was richer in terms of macronutrients (C, N, P) supporting high microbial diversity than MGB-2. Taxonomic vis-à-vis functional analysis identified Burkholderia, Bradyrhizobium, Mycobacterium, and Rhodopseudomonas as the keystone degrader of PAH and PCB. Overall, our results revealed the importance of metagenomic together with physicochemical analysis of contaminated site which improves the understanding of metabolic potential and adaptation of bacteria growing under stressful environment.

\section{Introduction}

Persistent organic pollutants (POPs) are anthropogenic chemicals that are enlisted in priority environmental pollutants due to their toxicity and persistence in the environment for a prolonged period (Jones and de Voogt 1998). PAHs/PCBs are strongly lipophilic and hence they easily enter the food chains. These characteristics are important since they are responsible for the detrimental effect on the environment and induce health threats to plants, animals, and humans (Engraff et al. 2011). Increased industrialization has led to the extensive production of such POPs which are also emitted during the production of steel (Zhang et al. 2015). The rise in these pollutant have led to adverse health and the environment effects, which inturn has resulted in extensive studies on the remediation of contaminated soil. Various physical and chemical technologies including chemical oxidation, electrokinetic remediation, solvent extraction, photocatalytic degradation, and thermal treatment are widely applied in remediation (Van Gerven et al. 2004). However, most of these treatment methods are unsustainable, disruptive and carry these PCBs/PAHs to the environment. Therefore, the utilization of existing contaminated soil-based bacterial communities can prove to be an alternative strategy for effective and viable degradation of POPs (Lu et al. 2019) as it has comparatively less technical hindrances than other remediation technologies.

A series of studies have been performed by the culture-dependent approach to isolate the most efficient biodegrader from such polluted sites (Issac et al. 2013). The contaminated soil environment consists of the genetic, species, and metabolic diversity of microbial biodegraders. Using a culture-dependent method only a minor fraction of POPs degrading bacteria can be obtained. Furthermore, it has been reported that enrichment of these cultures under lab conditions is less efficient in biodegradation than indigenous bacteria present in the contaminated soil (Isaac et al. 2015). To date, information related to taxonomic and functional interaction amongst the microbial communities that occur during the biodegradation process within the contaminated environment is skewed. The recent development of powerful culture-independent metagenomic approaches and the advancement of next-generation sequencing (NGS) technology provides a comprehensive insight into the total microbial community inhabiting contaminated sites and their metabolic capabilities. Several metagenomics studies conducted on PAH/PCB contaminated soil samples (Zhang et al. 2019) have highlighted microbial interaction playing a pivotal part in bioremediation of these POPs. Metagenomic sequencing technology such as Oxford Nanopore Technology (ONT) is very sensitive and can detect very low abundant microbial members present in the metagenome that are otherwise missed.

The present study aimed to investigate and provide an insight into the bacterial community in soils contaminated with such as PAH, PCB and to correlate their functional characteristics with respect to the biodegradation pathways. The soil samples were collected from nearby regions of Bhilai steel plant (one of Asia's biggest steel plants) in Chhattisgarh, India. The PCBs congeners and PAHs have been reported to be present in the wastes sites of industrialized area of this steel plant, India (Singh et al. 2015). The major pollution source of steel industries includes sinter, coke, and the blast furnace (Jiun-Horng et al. 2007).

The present study is the first comprehensive report on microbial community and metabolic potential with respect to biodegradation pathways of soil collected from polluted site nearby region of Bhilai steel plant.

\section{Materials And Methods}

\section{Study site and sampling}

The soil samples were collected from 2 different sites i.e sludge site (MGB-2) and dry soil waste site (MGB-3) from the polluted area near Bhilai steel plant, Chhattisgarh $\left(21.1915^{\circ} \mathrm{N}, 81.4041^{\circ} \mathrm{E}\right)$, in India (Fig 1). Soil samples were randomly collected in sterile containers from a depth of about 0 to $10 \mathrm{~cm}$ of two sampling sites. It was then transported on ice pack and were stored at $4{ }^{\circ} \mathrm{C}$ in the lab for analyses. Physicochemical parameters such as $\mathrm{pH}$, electrical conductivity, organic C, N, P, Mg, K, Na, Cl, Ca, S, Zn, Fe, Cu, and Mn of MGB-2 and MGB-3 were estimated using the standard protocol at the National Horticultural Research and Development Foundation, Nasik, India.

\section{Extraction and determination of PAH and PCB in sediments}

$5 \mathrm{~g}$ of each collected sample (dry weight) was added into $50 \mathrm{ml}$ Milli Q (MQ) water and was homogenized by vortexing for $15 \mathrm{~min}$. After allowing it to stand for $30 \mathrm{~min}, 10 \mathrm{ml}$ of acetone and hexane $(1: 1 ; \mathrm{v} / \mathrm{v})$ were added to the falcon and was vortexed for $3 \mathrm{~min}$. $2 \mathrm{~g} \mathrm{NaCl}$ was added and shaken vigorously for a few min (He et al. 2015). It was then centrifuged at $4000 \times \mathrm{g}$ for $5 \mathrm{~min}$. The supernatant was subjected for further solid-phase extraction (SPE) of PCB and PAH using bond elute cartridge as per manufacturer's instruction (Agilent technologies, USA). The cartridge was conditioned with $2 \mathrm{ml}$ acetonitrile for 2 min at 1000 $\mathrm{x} g$ followed by repeated conditioning with $2 \mathrm{ml} \mathrm{MQ}$ water. Extracted sample $(2 \mathrm{ml})$ was loaded onto the cartridge and centrifuged for $5 \mathrm{~min}$ at $4000 \mathrm{xg}$. This step was repeated twice. Further, the sample elution was performed with methanol and hexane 1:1 ( $/ \mathrm{v}$ ) in $5 \mathrm{ml}$ MQ by centrifuging for $2 \mathrm{~min}$ at $1000 \mathrm{x}$. The 
final elute was then collected through a Polytetrafluoroethylene (PTFE) filter ( $0.22 \mu$ ) in a separate vial and adjusted to $1 \mathrm{ml}$ with nitrogen (Weiland-Brauer et al. 2017). GCMS-TQ8040 (Shimadzu, Japan) fitted with Scan/SIM was used for the qualitative analysis of PAHs and PCBs that are potentially present in the MGB-2 and MGB-3 samples. GC-MS/MS fitted with Flame ionization detector (FID) and an RTX-5 column $(30 \mathrm{~m} \times 0.32 \mathrm{~mm} \times 0.25 \mu \mathrm{m})$ was used for analysis. GC conditions were set at $40^{\circ} \mathrm{C}$ with a $2 \mathrm{~min}$ hold and $10^{\circ} \mathrm{C} / \mathrm{min}$ increment to $80^{\circ} \mathrm{C}$, then $6{ }^{\circ} \mathrm{C} / \mathrm{min}$ to $225^{\circ} \mathrm{C}$ with 10 min hold. The presence of $\mathrm{PCB}$ was detected through SIM mode of GC-MS/MS.

\section{Metagenome Sequencing and analysis}

\section{DNA extraction and processing for metagenome}

Soil samples MGB-2 and MGB-3 were collected in triplicate and pooled together for each sample. DNA extraction was done using Powersoil ${ }^{\circledR}$ DNA Isolation Kit (Qiagen, USA) following the manufacturer's instructions. The metagenomic DNA sample was checked for integrity by agarose gel (1\%) using a BioRad Gel documentation system and was quantified by Qubit 3.0 Fluorometer (Invitrogen, USA).

\section{Preparation of library and whole metagenome sequencing}

Metagenomic DNA from MGB-2 and MGB-3 were end-repaired using NEBnext ultra II kit (New England Biolabs, USA), cleaned up with 1x AmPure beads (Beckmann Coulter, USA). Native barcode ligation was performed with NEB blunt/TA ligase using NBD103 and cleaned with 1x AmPure beads. Qubit quantified barcode ligated DNA samples were pooled at an equimolar concentration to attain a $1 \mu \mathrm{g}$ pooled sample. Adapter ligation (BAM), cleaning of library mix and elution of sequencing library were done as per the protocol by Gutierrez et al, 2018 and futher were used for whole-genome sequencing. The wholegenome library was prepared by using a Native Barcoding kit (EXP-NBD103). Barcode sequences are detailed in the supporting information (Table S1). The sequencing was performed using SpotON flow cell (R9.4) on MinKNOW 2.1 v18.05.5 with a $48 \mathrm{~h}$ sequencing protocol (Laver et al. 2015) on GridION X5 (Oxford Nanopore Technology (ONT, UK).

\section{Data processing and analysis}

The Nanopore raw reads ('fast5'format) were base-called ('fastq5'format) and demultiplexed using Albacore v2.3.1 and were uploaded to MGRAST server (version 4.0.3) for taxonomic and functional analysis (Keegan et al. 2016). Functional annotation by SEED subsystems helps in predicting the abundance of genes assigned to metabolic pathways in soil. The sequenced reads were interpreted using multisource non-redundant ribosomal RNA database for taxonomic diversity and were determined using the contigLCA algorithm against the M5NR database for samples analyzed via whole-genome sequencing (WGS) (MG-RAST metagenome MGB-2 and MGB-3 identification numbers = mgm4822000.3, mgm4822001.3). The interpretation was based on Evalue cut-off $=1 \times \mathrm{e}^{-5}$ and sequence identity of $60 \%$ (Randle-Boggis et al. 2016; Brumfield et al. 2020).

\section{Statistical analysis}

Various alpha diversity indices were calculated to study species richness and evenness of the MGB-2 and MGB-3 using PAST4.03 software. Principal component analysis (PCA) plot was constructed using Bray-Curtis matrices with R studio v3.1.2. Comparison of samples MGB-2 and MGB-3 was done using Statistical Analysis of Metagenomic Profiles software (STAMP; Parks and Beiko, 2010) with a two-sided G-test (w/Yates'+ Fischer's). Comparative metagenome analysis was done mainly with RefSeq and SEED subsystem to obtain genus/functional abundance, respectively. Cytoscape software v3.7.1 was used to generate networking plots for study of the interaction of microbial communities of MGB-2 and MGB-3 involved in xenobiotic biodegradation pathways.

\section{Results And Discussion}

\section{Physico-chemical analysis of the MGB-2 and MGB-3}

Microbial community structure and function are determined by various environmental factors including nutritional status that in turn are governed by various physico-chemical parameters. Therefore, the physicochemical properties of the MGB-2 and MGB-3 were determined and are summarized in Table 1. The sample MGB-3 was richer in terms of macronutrients such as carbon (C), nitrogen (N), phosphorus (P) that greatly influence the composition of the microbial community (Luo et al. 2020). The organic carbon content, which represents the energy flow in the carbon cycle, was $0.85 \%$ (slightly high) in MGB-2 and $1.39 \%$ (high) in MGB-3 as compared to reference values. Our results indicated high carbon content in the given samples that could be because of aromatic organic hydrocarbons present in the contaminated soil. Industrial soil and effluent are considered to be a source of organic contaminants including POPs like PAHs (Cai et al. 2007). Because of the hydrophobic nature of these POPs, they tend to bind with the soil and hence add to the organic carbon content of the soil. The sample MGB-3 had very high nitrogen and phosphorus content ( $\left.N, 734 \mathrm{~kg} \mathrm{ha}^{-1} ; \mathrm{P}, 56.9 \mathrm{~kg} \mathrm{ha}^{-1}\right)$ whereas MGB-2 had moderate nitrogen (430 kg ha $\left.{ }^{-1}\right)$ and low phosphorus (17.66 kg ha-1) content. MGB-3 exhibited high $\mathrm{P}$ and low C/P ratios indicating the possibility of higher microbial diversity as compared to the MGB-2. Several studies have confirmed that the soil with high microbial diversity has high $\mathrm{P}$ and low $\mathrm{C} / \mathrm{P}$ ratios, while the environment with less $\mathrm{P}$ and high $\mathrm{C} / \mathrm{P}$ ratios shows low microbial diversity (Delgado-Baquerizo et al. 2017). A higher level of these micronutrients in MGB-2 can be due to the high water content in the sample. Further, these results indicate that both MGB-2 and MGB-3 can support diverse microbial communities.

Overall, the level of micronutrients including K, Mg, Na, Mn was higher in MGB-2 than MGB-3. The level of K (1232 kg ha-1) and Mg (768 kg ha-1 $)$ was found to be higher than the reference value in MGB-2. The availability of inorganic nutrients serves for structural as well as catalytic functions. Therefore, it is supported with the fact that the total taxonomic and functional profile of the bacterial communities are predominantly driven by the availability of $\mathrm{C}$ and $\mathrm{N}$ and also by the presence of inorganic nutrients i.e., $\mathrm{Ca}, \mathrm{K}$ and $\mathrm{Mg}$ to some extent (Nicolitch et al. 2019). The result of the metal analysis indicated that the MGB-3 had comparatively higher metal content ( $\mathrm{Zn}, \mathrm{Cu}$, and Fe) than the MGB-2 (Table 1). The result also indicated a high percent of Mn (44.12 mg kg-1) 
in MGB-2 and Fe (14.98 mg kg-1) in MGB-3, providing a suitable environment for microbes to undergo anaerobic biodegradation. The high metal content in both samples was due to the additives used in a steel factory. The presence of the metals in a soil sample can limit many microbial species whereas they can support the survival and growth of metal tolerant species. The presence of metals is in accordance with several reports that highlighted the presence of heavy metals along with organic contaminants such as PAH from iron and steel industrial soil sites (Bano et al. 2018). In addition, Mn(IV) and Fe(III) are known to act as terminal electron acceptors that efficiently remove aromatic compounds from the soil. Fe is the most widely found cofactor involved in deoxygenation reactions in biodegradation studies. It has been reported that Fe containing dioxygenases is incorporated into the active site either as iron center, Rieske [2Fe2S] cluster or as heme prosthetic group during PAH and PCB biodegradation (Langenhoff et al. 1996).

\section{Determination of PAH and PCB residues in contaminated soil samples}

Cities with long industrial history contribute to the addition of organic pollutants in soil (Jiang et al. 2018; Ontiveros-Cuadras et al. 2019). Hence it was deemed fit to estimate the level of POPs mainly PAH and PCB in given soil samples by GC-MS/MS using Scan/SIM mode. GC-MS/MS triple quadrupole allows detection at very low (femtogram) limits in the matrix through the use of even greater selectivity with selected reaction monitoring (SIM) mode. Based on the data obtained from GC-MS/MS analysis, various PAHs along with PCB in industrial soil sample were identified. The structure and the relative percentage abundance of PAH identified in MGB-2 and MGB-3 are given in Fig 2. F (15.89\%) and BkF (11.29\%) were found to be dominant PAH species in MGB-2, while Pyr (18.7\%) and BaA (17.69\%) in MGB-3. High-molecular-weight (HMW; 4-6 rings) PAHs namely BcPhe (0.51\%), BkF (11.29\%), F (15.89\%), IcdP (6.63\%), Per (5.23\%), and Tpl (4.70\%), predominated in the MGB-2 sediments, which were not detected in MGB-3 (Fig 3). PAHs such as Indeno (1,2,3-cd) pyrene, benzo (k) fluoranthene, dibenzo $(a, h)$ anthracene, chrysene, fluoranthene, acenaphthene, and fluorene have been reported to be in different operational units of steel industry (Khaparde et al. 2016).

In addition to PAHs, the MGB-2 and MGB-3 was also found to be contaminated with PCBs such as biphenyl, 1,1'-biphenyl, 4,4'-dichloro (PCB-15) in MGB-2 and biphenyl, 1,1'-biphenyl 2,2',3','5,6 pentachloro (PCB-95) and 1,1'-biphenyl 2,2',3,3',6,6' hexachloro (PCB-136) in MGB-3 (Fig. S1-S2) (Aydin et al. 2014). It is well studied that the carcinogenic risk increases with the molecular weight or the aromatic ring of PAHs (Yang et al. 2002) and with the chlorine atoms in the case of PCBs. However, the data of source of PCBs has been scarce in industrial regions. The present results are in accordance with previous studies conducted by Patel et al. 2015 on Bhilai steel plant (Raipur, Chhattisgarh) soil, reporting the presence of PCBs ranging from of dichlorinated to hexachlorinated biphenyl in the sludge. From the data of organic contaminants, it appears that the high carbon content in MGB-2 and MGB-3 mentioned in the previous section could be co-related with the abundance of PAH and PCB in the soil sample.

\section{Metagenomic analysis}

\section{Whole Genome Sequencing and assembly summary}

The metagenomic approach provides a complete picture of biodegradation vis-a-vis microbes present within the environment and the functional genes involved in the bioremediation of contaminants. Whole-genome metagenomics studies are used not only for studying taxonomic diversity but also for elucidating metabolic pathways required for understanding pollutant degradation (Bouhajja et al. 2016). ONT has gained attention in recent times for community analysis due to its advantages over short-read sequencing technologies due to its ability of sequencing through repetitive regions within few minutes (Cummings et al. 2017). In the present study, the ONT platform for community analysis was used as it enables unbiased assembly of complete genome sequencing. Nanopore GridION X5 generated real-time, long-read, high-fidelity DNA sequence data. MG-RAST statistical analysis of dataset provided 275,844 sequences (totalling 539,360,072 bp; average length 1,955 bp) for MGB-2 and 193,221 (totalling 532,031,111 bp; average length 2,753 bp) for MGB-3. The downstream analyses of the total number of reads are detailed in Table S2. The datasets were used for various taxonomic, ecological, and functional analyses as described in previous section.

\section{Analysis of sequence data for the extent of microbial diversity}

The horizontal rarefaction curve indicated the significant depth of sampling, hence, represents sufficient sample coverage for diversity analysis (Fig S3). MGB2 and MGB-3 comprised 1839 and 1884 species respectively, indicating higher species richness in MGB-3 that is also evident from the data of Chaoa. The various diversity indices depicted in Table 2 suggest equivalent overall diversity which considers both species richness and abundance. MGB-3 was more diverse as compared to MGB-2 as calculated by Chao- $a$ and Shannon's diversity (Table 2). Higher species richness in MGB-3 may be due rich C, N, and P content which are a major determinant of microbial growth (Cleveland and Liptzin, 2007). Beta diversity among MGB-2 and MGB-3 based on Bray-Curtis dissimilarity (Fig 4) depicted the overall distribution pattern of bacterial communities in MGB-2 and MGB-3 samples. Principal coordinates PC1 showed 98.7\%, bacterial communities' ordinated closer to one another across axes are more similar in the two sites (MGB-2 and MGB-3) than $1.71 \%$ bacterial communities.

\section{Taxonomic diversity and total microbial community}

ONT and MG-RAST database search provided detailed microbial taxonomy of MGB-2 and MGB-3. Major differences were noticeable at the domain level, where MG-RAST derived reads accounted for bacteria (97.4\%; $97.5 \%)$ followed by Eukaryota $(1.4 \% ; 1.5 \%)$, archaea $(1.2 \%$; $0.9 \%)$ and virus $(0.02 \%$; $0.04 \%)$ in MGB-2 and MGB-3, respectively. Comparison of the most abundant bacteria between samples, distribution of bacteria at phylum, order, class, family, and genus level as depicted in Krona plots representing the relative abundance of different bacterial genera identified in the two samples (Fig $5 a-b)$. Among bacteria, phylum Proteobacteria (43.3\%; 50.0\%) was the most predominant followed by Actinobacteria (22.1\%; 19.5\%) and Firmicutes (6.3\%; 5.4\%) in both MGB-2 and MGB-3 samples. The predominance of Proteobacteria and Actinobacteria in the soil sample indicated good biodegradation capability, as similar observations were found in contaminated sites of PAH, PCB, and other related pollutants (Lu et al. 2019). Also, the abundance of Proteobacteria reveals that the microbial community plays a vital role in photosynthesis, nitrogen fixation, sulfur, and phosphorus metabolism. Both the sample included all six classes of bacteria namely Alphaproteobacteria (18.6\%; 22.4\%), Betaproteobacteria (8.8\%; 10.7\%), Deltaproteobacteria (8.2\%; 7.1\%), Epsilonproteobacteria (0.3\%; 0.3\%), 
Gammaproteobacteria $(7.2 \% ; 8.9 \%)$ and Zetaproteobacteria $(0.04 \% ; 0.03 \%)$ with difference in their relative abundance as observed by Ma et al. 2015 as well. At class level, Actinobacteria (26.2\%) was observed to be dominant in MGB-2 while Alphaproteobacteria (22.1\%) in MGB-3. STAMP analysis with G-test (w/Yates'+ Fischer's) two-way comparison showed the degree of closeness and difference across MGB-2 and MGB-3 at class level. The analysis showed close similarity in both metagenome, however they differ in relative abundance. Among the classes, Actinomycetales (85.7\%; $88.4 \%$ ) were found to be distinctly observed in MGB-2 and MGB-3 followed by Solirubrobacterales (8.6\%; 6.7\%).

At the genus level, the composition of the bacterial community in the two samples was similar but they differed in terms of their relative abundance. Streptomyces (3.7\%) and Candidatus Solibacter (2.7\%) were the most predominant genera in MGB-2, while in MGB-3 it was Mycobacterium (3.1\%) and Streptomyces (3.0\%). RefSeq annotations at highest taxonomic classification i.e., at genus level possess significant abundance level with $\mathrm{p}<1 \mathrm{e}^{-5}$ for Streptomyces, Candidatus Koribacter, Gemmata, Conexibacter, Anaeromyxobacter and Nocardioides in MGB-2, while Hypomicrobium,

Pseudomonas, Mycobacterium, Roseomonas, and Methylobacterium with $\mathrm{p}<1 \mathrm{e}^{-5}$ in MGB-3. The correlation coefficient $\left(r^{2}\right)$ indicated a linear relationship between MGB-2 and MGB-3 as depicted on the scatter plot (Fig S4). The dominance of Mycobacterium in MGB-3 can be correlated with the presence of pyrene in MGB-3, as it have been reported to be isolated from pyrene contaminated soil (Cheung and Kinkle, 2001). Mycobacterium has the ability to degrade pyrene. The presence of the dominant genera in samples suggests the potential for degrading organic pollutants by the members of these genera. For instance, Anaeromyxobacter is known to be capable of anaerobic respiration and possesses genes involved in reductive dechlorination processes at contaminated sites (Stanford et al. 2002). Similarly, members of Mycobacterium, Bradyrhizobium, Burkholderia (Goris et al. 2004; Rodrigues et al. 2006), and Pseudomonas (Wittich et al. 1999; Hatamian- Zarmi et al. 2009) are well known aromatic pollutant degraders in contaminated soil (Seo et al. 2009).

Within the metagenome of MGB-2 and MGB-3, Archaeal communities showed dominance of Euryarchaeota (76.7\%; $81.3 \%)$ at phylum level followed by Crenarchaeota $(13.7 \% ; 13.2 \%)$ and Thaumarchaeota $(8.7 \% ; 4.8 \%)$, Korarchaeota $(0.9 \% ; 0.7 \%)$. At genus level relative abundance for methane-producing Methanosarcina (10.5\%; $12.1 \%)$ Methanoculleus (3.7\%; 3.2\%) ammonia-oxidizing Nitrosopumilus (5.9\%; 3.3\%), Sulfur reducing bacteria like Thermococcus (4.3\%; 4.7\%) unclassified (derived from Euryarchaeota) (4.3\%; 4.2\%), Pyrococcus (3.9\%; 3.3\%), Sulfolobus (3.6\%; 3.3\%) dominated in both MGB-2 and MGB-3. However, two-way statistical comparison at Archaea genus level revealed Nitrosopumilus $\left(p=1.24 \mathrm{e}^{-4}\right)$ and Cenarchaeum $\left(p=5.18 \mathrm{e}^{-3}\right)$ in MGB-2 while Methanobrevibacterium ( $p=0.012$ ) in MGB-3 to predominate indicating more methanogenesis occurring in MGB-3 (Samson et al. 2019). The contaminated soil was reported to possess many members of Methanosarcina, Halobacterium, Euryarchaeota, and Crenarchaeota of uncultured genera. The diversity of Archaea is found to be higher within hydrocarbon degrading communities in contaminated environment than the non-contaminated counterpart. (Zhang et al. 2012). The relative abundance of Archeal communities was more in MGB-2 that can be associated with the higher soil moisture and POPs content.

Eukaryota microbial communities showed a predominance of phylum Ascomycota (20.5\%; 23.6\%), Streptophyta (18.5\%, $17.0 \%)$ and unclassified (derived from Eukaryota) $(12.1 \% ; 12.2 \%)$ in MGB-2 and MGB-3. Several studies conducted on contaminated soils have revealed the presence of Ascomycota as the most dominant eukaryotic phylum, as the indigenous ascomycete can transform or remove the pollutants (Aranda, 2016).

\section{Functional diversity and metabolic potential of MGB-2 and MGB-3}

The SEED subsystem analysis in MG-RAST assigned reads based on various functions that identified $60 \%$ of the total function constituting metabolisms of amino acid, carbohydrate, energy, lipid, cofactors, vitamins, biosynthesis of glycan, polyketides, terpenoids, xenobiotic biodegradation, and biosynthesis of secondary metabolites. The remaining $40 \%$ functions include cellular processes, organismal systems, genetic \& environmental processing, and human diseases.

\section{General metabolism of microbial community}

Metagenomic analysis revealed the coordination amongst the bacteria and different functional genes detected in metabolic pathways. Further, it is known that under stress conditions requires extra energy metabolism. Annotated genes involved in methane, $\mathrm{C}, \mathrm{N}$, and S metabolism pathways were identified. Predicted genes from the MGB-2 and MGB-3 metagenome were used as input in the KEGG mapper for functional annotation. Table 3a depicts a list of genes responsible for methane metabolism that are mainly attributed to methanotrophs and methanogens. It indicated the presence of hydrogenotrophic and methylotrophic methanogenesis pathways in both metagenomes. The presence of members belonging to Nocardioides (11\%) and Methylobacterium (12\%) were the major potential contributors of methanogenesis in MGB-2 and MGB-3, respectively. At the same time, the predominance of archaeal members belonging to Methanosarcina, Methanoculleus, and Methanothermobacter predominant in MGB-3 indicated more methane metabolism as compared to MGB-2.

Metagenome sequences analysed for nitrogen metabolism resulted in the identification of genes annotated for nitrate reductase (napA, nap $B$ ), nitrite reductase (nirB, nirD, nirK, nirS), and nitric oxide reductase (norB, norC, nosD, norZ) in both the metagenome. Based on the number of reads, the dissimilatory $\mathrm{N}$ metabolism was noted to be more dominant than the assimilatory in both metagenome, which indicated cellular metabolism is more active than the cell synthesis process in the contaminated soil. The genome of the microbial communities also showed potential for the biological nitrogen fixation process which was evident from the presence of genes encoding the enzyme ( ifB, nifE nifK, nifM) responsible for nitrogen fixation to ammonia. Bacteria playing a dominant role in $\mathrm{N}$ metabolism at genus level in this study are similar to that of industrial polluted sites reported by Devpura et al. 2017. The absence of nitrogen-fixing reads can also be related to the high nitrogen (biologically available) and presence of aerobic conditions in MGB-3. The relative abundance of N metabolism reads accounted for Rhodopseudomonas (11\%) in MGB-2, whereas it was for Mycobacterium (14\%) reads in MGB-3 at the genus level. These genes related to nitrogen fixation were assigned to nitrogen-fixing bacteria like Bradyrhizobium, Frankia, Mesorhizobium, Sinorhizobium, and Rhizobium in MGB-2 only, because of high water content. Also, Nitrite-oxidizing bacteria (NOB) and Ammonia oxidizing (AOB) that are responsible for conversion of $\mathrm{NO}_{3}$ to ammonium namely Nitrosomonas, Nitrospira, and Nitrobacter were identified in MGB-2. However, no nitrogen fixation reads were identified in MGB-3. Genes encoding sulfite reductases belonging to the oxidoreductase family were found in both the metagenome. Assimilatory sulfate reduction involves oxidation of

Page 5/26 
sulfate to hydrogen sulfide through series of enzymes identified and are provided in Table 3b. Anaeromyxobacter, Haliangium, Methylobacterium were dominant in MGB-2, while Mycobacterium, Conexibacter, Bordetella, and Pseudomonas in MGB-3. Comparative analysis of both the metagenome based on their metabolism at SEED level 1 revealed significant dominance of methane metabolism $\left(p=5.61 e^{-4}\right)$, citrate cycle $\left(p=1.62 e^{-3}\right)$, carbon fixation $\left(p=2.61 e^{-}\right.$ $\left.{ }^{3}\right)$, pyruvate metabolism $\left(5.80 \mathrm{e}^{-3}\right)$, aminobenzoate degradation $(p=0.031)$, selenocompound metabolism $(p=0.038)$ and benzoate degradation $(p=0.045)$ in both samples. However, lipoic acid metabolism $\left(p=7.58 \mathrm{e}^{-4}\right)$, drug metabolism $\left(p=7.81 \mathrm{e}^{-3}\right)$, folate biosynthesis $(p=0.17)$, fatty acid metabolism $(p=0.042)$ and lysine degradation $(p=0.042)$ were found to be comparatively high in abundance in MGB-3 (Fig 6a). It also revealed significant dominance of Intrasporangum $\left(<1 \mathrm{e}^{-5}\right)$, Rubrobacter $\left(<1 \mathrm{e}^{-5}\right)$, Candidatus Koribacter $\left(<1 \mathrm{e}^{-5}\right)$, Norcardiodes $\left(1.77 \mathrm{e}^{-4}\right)$, Anaeromyxobacter $\left(4.71 \mathrm{e}^{-4}\right)$ in MGB-2 while Mycobacterium ( $\left.<1 \mathrm{e}^{-5}\right)$, Hypomicrobium $\left(<1 \mathrm{e}^{-5}\right)$, Mesorhizobium $\left(<1 \mathrm{e}^{-5}\right)$, Rhodobacter $\left(<1 \mathrm{e}^{-5}\right)$, Methylobacterium $\left(<1 \mathrm{e}^{-5}\right)$, Pseudomonas $\left(1.65 \mathrm{e}^{-4}\right)$ and Burkholderia $\left(3.33 \mathrm{e}^{-3}\right.$ ) in MGB-3 (Fig 6b). The results indicated the active metabolism is represented by bacteria belonging to phylum Actinobacteria in MGB-2 while Proteobacteria in MGB-3.

The comparative analysis of gene sequences revealed abundance of $\mathrm{P}$ transporter in MGB-2 that can be correlated with the low P content than MGB-3. Various genes encoding proteins involved in phosphate-recycling mechanisms, such as phnA, phnE, phnWand phnX, (phosphonate transporters), pst $A$, pstB, pstC, and pstS (high-affinity phosphate transporters), and phoR, phoA, phoP and phoD (two-component systems) were detected across both the metagenome (Fig S5a). The availability number and abundance of reads for phosphate mechanism in low phosphate-phosphorous environment indicated these mechanism that helps them to cope up within such environment. Moreover, bacteria can survive due to the presence of resistant genes toward toxic metals such as copper, lead and nickel as a part of their defense mechanism, which is recruited further for cleaning the contaminated environments. The bioavailability of metals depends upon their interaction with the organic compounds present in the soil. The high abundance of Mn content in MGB-2 can be supported with the significantly high reads for Mn transporter in MGB-2 than MGB-3.

Bacteria survive by expressing several metal-resistant $\mathrm{Cu}(\mathrm{I})$-responsive transcriptional regulator proteins. Genes corresponding to the above-mentioned functions were identified in the metagenome that leads to the accumulation of $\mathrm{Cu}(\mathrm{I})$ in an anoxic environment (Giachino $\mathrm{A}$ and Waldron $\mathrm{KJ}$, 2020). $\mathrm{Mn}$ and $\mathrm{Co}$ efflux protein CorC were identified in both metagenomes. Cu homeostasis and tolerance genes namely CutE and CutC were found to be in abundance for Bacillus, Candidatus, Kineococcus, Mesorhizobium, Mycobacterium, Parvibaculum, Salinispora, Streptosporangium in MGB-2, and Nocardioides, Thiobacillus, Idiomarina, Rhodopseudomonas, Aromatoleum, and Bacillus in MGB-3. The distinct relative abundance of iron acquisition and metabolism reads was observed for Pseudomonas (22\%; 26\%) in MGB-2 and MGB-3, respectively. Further investigation resulted in the identification of siderophore-producing bacteria Pseudomonas (43\%; 51\%) and Streptomyces (13\%; 5\%) in both samples. The comparative analysis reflected the higher dominance of iron metabolizing bacteria in MGB-3 than MGB-2 that is well matched to the data of soil analysis in terms of higher iron content in MGB-3 than MGB-2. The primary mechanism of $\mathrm{Zn}$ uptake involves $\mathrm{ABC}$ transporters such as $z n u A$, znuC, and znuR. These $\mathrm{Zn}$ transporters present in both metagenome aids in transporting $\mathrm{Zn}$ across the membrane. Secondary mechanism of $\mathrm{Zn}$ uptake by cation transporters $\mathrm{Zn}$ tolerance reads at genus level was most dominant for Anaeromyxobacter (40\%; $41 \%$ ) in MGB-2 and MGB-3. Comparison between MGB-2 and MGB-3 of functional gene annotation using SEED subsystem for membrane transport revealed a significant level $\left(p>0.05\right.$ ) of abundance for $\mathrm{Na}^{+} / \mathrm{H}^{+}$antiporters and $\mathrm{Mn}$ transporter MntH, Mn ABC transporter SitD, TadA, Zn ABC transporter ZnuA (Fig S5b1d). MGB-3 showed higher $\mathrm{Na}^{+} / \mathrm{H}^{+}$transporters indicating the exchange of the ions across the membrane to maintain homeostasis.

\section{Abundance of Xenobiotics degradation and metabolism gene related to biodegradation}

Overall, 708 (MGB-2) and 760 (MGB-3) annotated genes with varying levels of abundance (Fig S6) in two samples were identified corresponding to 17 pathways linked with xenobiotic biodegradation and metabolism. It was found that the annotated pathways for xenobiotic degradation and metabolism accounted for $2 \%$ of all $60 \%$ metabolic functions (Fig 7a). The presence of these pathways is of great relevance as they are POPs enlisted by the U.S. Environmental Protection Agency. The presence of reads for biphenyl degradation, dioxin degradation, PAH pathways can be further correlated with the presence of PCB and PAH as detected in the MGB-2 and MGB-3 samples (Fig 7b). Further, chlorocyclohexane and chlorobenzene [PATH: Ko00361], and benzoate [PATH: Ko00362] degrading pathway were most prominent in MGB-2 (33.76\%; 37.39\%) and MGB-3 (39.55\%; 33.96\%). In addition to these degradative pathways, dioxin [PATH: Ko00621] and PAH [PATH: Ko00624] degradation pathways were also observed in MGB-2 (3.27\%; 2.54\%) and MGB-3 $(4.29 \% ; 2.80 \%)$ respectively. It is reported that chlorobenzene, PAH, PCB and benzoate are prominent contaminants of dye and steel industries.

The annotated enzymes hydroxyquinol 1,2-dioxygenase (chqB), pentachlorophenol 4-monooxygenase ( $p c p B)$, chorismate mutase/prephenate dehydratase (pheA), carboxymethylenebutenolidase $(c / c D)$, haloacid dehalogenase ( $h a d L)$, benzene 1,2-dioxygenase/ toluene 1,2-dioxygenase (bedC1/todC1), biphenyl-2,3diol 1,2-dioxygenase $(b p h C)$, catechol dioxygenase (catA), and muconate cycloisomerase (catB) were contributed mainly by members of genera in two communities suggesting coordinated degradation of chlorocyclohexane and chlorobenzene compounds depicted in Table 4a. Studies on chlorobenzene biodegradation highlighted that these compounds metabolized via the ortho-cleavage pathway (Mars et al., 1999) as well as by the meta-cleavage pathway (Mars et al., 1997).

Biphenyl degradation with annotated reads for $b p h A, b p h C, b p h D, b p h E$, and $b p h F$ were identified in both the metagenome. The abundance and diversity of the biphenyl/PCB enzyme and the corresponding bacterial genera in both the metagenome are listed in Table $4 \mathrm{~b}$. The annotation of $b p h \mathrm{~A}$ in both the metagenome MGB-2 and MGB-3 have indicated biphenyl degradation assigned to genus Mycobacterium in both the metagenome. In addition to Mycobacterium, it was also assigned to Polaromonas in MGB-3. Biphenyl 2, 3-diol, 1, 2-dioxygenase (bphC) is another important enzyme that was noted in both the metagenome. It has been assigned to Mycobacterium in MGB-2 while genus Alkalilimnicola, Mycobacterium, and Polynucleobacter in MGB-3. Aerobic and anaerobic degradation of PCB by bacteria have been studied in detail (Komancova et al. 2003; Jorge et al. 2006).

PAH degradation pathway was identified in MGB-2 and MGB-3 with annotated genes encoding enzymes required for degradation being listed in Table 4c. The presence of genes encoding hydroxychromene-2-carboxylate isomerase (nahD), naphthalene dioxygenase (nahAc), salicylate hydroxylase (nahG), and other 
genes including nidA, nidB, nidD, phdF, phdG, phdl, and phdJ indicated complete pathway for degradation of PAH. The presence of reads for nidA gene was significantly correlated with the degradation of pyrene (Lu et al. 2019) that is in accordance with the presence of pyrene in metagenome MGB-3 detected by GC-MS/MS. It is reported that nidA gene is responsible for the synthesis of the large subunit of PAH dioxygenase involved in the degradation of PAHs such as phenanthrene, pyrene, benzo[a]pyrene, etc. (Pagnout et al. 2007). These enzymes are contributed by members of genera Pseudoalteromonas, Aromatoleum, Dechloromonas, Agrobacterium, Mesorhizobium in MGB-2, while Mycobacterium, Parvibaculum, Ruegeria, Burkholderia, Aromatoleum, Bradyrhizobium in MGB-3 communities suggesting synergistic degradation of these PAH.

Annotated gene/enzyme and assigned bacterial genera involved in benzoate degradation pathway identified in MGB-2 and MGB-3 are listed in table 4c. The presence of benzoate ligase in MGB-2 indicated anaerobic degradation of benzoate. Benzoate is the most common intermediate in the metabolism of aromatic compounds and in the anaerobic condition, it is converted into benzoyl-CoA by benzoate ligase. The presence of genes encoding anaerobic degradation via benzoyl coA (badA, badD, badE, badF, badH, badl, hbaA, hbaB, hcrC) and aerobic via protocatechuate (ligAB, ligC, ligl, ligJ, pobA, pcaB, $p c a C, p c a D F, p c a G H$ and pcalJ) catechol (catE/ $d m p B$ ) indicates complete pathway for degradation of benzoate. Protocatechuate can be mineralized via ortho- cleavage by protocatechuate 3,4-dioxygenase (PcaGH) and meta cleavage by protocatechuate 4,5-dioxygenase (LigAB). Anaerobic degradation via benzoyl-CoA has also been documented in a variety of facultative anaerobes, the denitrifying Thauera (Heider et al. 1998), Aromatoleum, Azoarcus (Valderrama et al. 2012), Magnetospirillum strains (Meyer-Cifuentes et al. 2017), and the photoheterotroph Rhodopseudomonas (Egland et al. 1995).These enzymes are contributed possibly by members of genera Aromatoleum, Arthrobacter, Burkholderia, Bradyrhizobium, Cupriavidus, Magnetospirullum, Methylobacterium, Rhodomicrobium, Rhodopseudomonas, and Polaromonas in both the metagenome communities suggesting synergistic degradation of benzoate. Comparison between MGB-2 and MGB-3 of functional gene annotation using SEED subsystem by STAMP for peripheral degradation revealed the abundance for, muconate cycloisomerase ring hydroxylating dioxygenase, naphthalene dioxygenase, acetaldehyde dehydrogenase, 2-hydroxy-6-oxo-6-phenyl hexa-2,4-dienoate hydrolase, and benzoate transport protein in MGB-2 while biphenyl 2,3 diol dioxygenase, benzaldehyde dehydrogenase, nap/bph dioxygenase, ortho-halobenzoate 1,2- dioxygenase, phenol dioxygenase, 1,2- dihydroxycyclohexa-3,5-diene-1-carboxylate dehydrogenate in MGB-3 (Fig.S5). Similarly, two-way comparison between MGB-2 and MGB-3 of functional gene annotation using SEED subsystem for aromatic degradation revealed significant level of abundance for benzoate ligase $\left(p=2.63 \mathrm{e}^{-3}\right)$ and 4-hydroxyphenylacetate 3-monooxygenase $\left(p=8.93 \mathrm{e}^{-3}\right)$ in MGB-2. The presence of 2hydroxycyclohexanecarboxyl dehydrogenase with $p=2.39 \mathrm{e}^{-3}$, indicates anaerobic degradation of benzoate in MGB-3 as well. However, aerobic degradation of biphenyl was also found in MGB-3 as indicated by the abundance of biphenyl-2,3-diol 1,2-dioxygenase with $p=0.035$ in MGB-3 (Fig. S7-S8). Further, comparison between MGB-2 and MGB-3 at functional gene annotation using RefSeq for aromatic degradation revealed significant level of abundance of Acidothermus $\left(p=2.68 \mathrm{e}^{-3}\right)$, Nakamurella $\left(\mathrm{p}=6.39 \mathrm{e}^{-3}\right)$ in MGB-2 while Mycobacterium $\left(\mathrm{p}=3.30 \mathrm{e}^{-3}\right)$, Leptothrix $\left(\mathrm{p}=7.89 \mathrm{e}^{-3}\right)$ and Polynuclearbacter $(\mathrm{p}=0.034)$ in MGB-3 (Fig. S9).

Our findings suggest that biphenyl (PCB) and pyrene/ phenanthrene (PAH) biodegradation pathways could be linked together via common intermediate protocatechuate pathway and undergoes complete degradation through the common protocatechuate branch of the $\beta$-ketoadipate pathway. Therefore, reconstruction of complete biphenyl/PCB and PAH degradative pathways based on the annotated genes was done and shown in Fig 8. Cytoscape-based networking revealed microbial interaction in the xenobiotic biodegradation pathway. The key biodegraders in xenobiotic biodegradation pathways (aromatic halogenated, dioxin, PAH, PCB/biphenyl, catechol, protocatechuate, benzoyl-CoA) were found to be Arthrobacter chlorophenolicus, Meiothermus ruber, Cupriavidus metallidurans, Burkholderia xenovorans, Rubrobacter xylanophilus, Bradyrhizobium sp. BTAi1, Bradyrhizobium japonicum, Sphingobium japonicum, Pseudomonas aeruginosa, Polaromonas sp. JS666 and Rhizobium leguminosarum in MGB-2 (Fig 9). In MGB-3 it was Bradyrhizobium japonicum, Rhizobium leguminosarum, Mycobacterium sp. KMS, Polaromonas sp. JS666, Rhodopseudomonas palustris, Xanthobacter autotrophicus, Mycobacterium smegmatis, Burkholderia cenocepacia, and Burkholderia xenovorans (Fig 10). The greater abundance of these genes and genera in sample MGB-2 compared to sample MGB-3 suggests that there higher degrading capacity in sample MGB-2. However, the key biodegrader were found to be Bradyrhizobium, Burkholderia, Mycobacterium and Rhodopseudomonas in both the metagenome.

\section{Conclusions}

The present metagenomic study highlighted microbial function annotation, extensive degradation capabilities in terms of xenobiotic degradation pathways and correlated with the presence of PAH and PCB in the contaminated soil of steel plant. In addition, physico-chemical profiling of the soil samples provided valuable information regarding the presence of organic (C/N/P), inorganic nutrient ( $\mathrm{Ca}, \mathrm{K}, \mathrm{Mg}, \mathrm{Na}, \mathrm{Mn})$ and metal (Fe, Mn, $\mathrm{Cu}, \mathrm{Zn}) \mathrm{present}$, that can be important parameter for designing biodegradation strategies. Higher proportions of Proteobacteria and Actinobacteria indicated the two sample possess good biodegradation potential. Moreover, the coordination among different biodegraders along with presence of functional genes involved in biodegradation pathways and energy metabolism has provided in-depth understanding regarding their survival under stress conditions of persistent organic pollutants. Moreover, these potential biodegrader such as Bradyrhizobium, Burkholderia, MycobacteriumRhodopseudomonas and Pseudomonas identified in the present study can be further selected and further could be exploited for enhancing bioremediation. Therefore, it can be concluded that investigating microbial community and exploring their potential for biodegradation is a critical factor in maximizing the efficacy of the bioremediation process.

\section{Declarations}

\section{Availability of data and materials}

All data generated or analyzed during this study are included in this published article and its supplementary information files

\section{Acknowledgements}


Our special thanks to Central instrumentation Facility, Birla Institute of Technology and Sciences (BITS), Pilani campus for providing GC-MS/MS facility. MS acknowledges financial assistance provided by DST, India.

\section{Funding}

Authors are thankful to Department of Science and Technology, New Delhi, India for financial assistance under Women Scientist Scheme B [SR/WOSB/570/2016] to MS.

\section{Author information}

\section{Affiliations}

Department of Biological Sciences, Birla Institute of Technology and Science Pilani, Pilani campus, Pilani-333031, Rajasthan, INDIA

Monika Sandhu \& Prabhat N. Jha

Department of Pharmacy, Birla Institute of Technology and Science Pilani, Pilani campus, Pilani-333031, Rajasthan, INDIA

Atish T. Paul

\section{Contributions}

M.S. and P.N.J. designed the project. A.T.P. designed GC-MS/MS based experiment and analyzed respective data. M.S. conducted all experiments. M.S. and P.N.J. analyzed and interpreted the results, and wrote the manuscript. All of the authors contributed to finalizing the manuscript.

\section{Correspondencing Author}

Correspondence to Prabhat N. Jha.

\section{Ethics declarations}

\section{Competing interests}

The authors declare that they have no known competing financial interests or personal relationships that could have appeared to influence the work reported in this paper.

\section{Ethics approval and consent to participate}

Not applicable.

\section{Consent for publication}

Not applicable.

\section{References}

Aranda E (2016) Promising approaches towards biotransformation of polycyclic aromatic hydrocarbons with Ascomycota fungi. Curr Opin Biotechnol 38: 1-8 Aydin YM, Kara M, Dumanoglu Y, Odabasi M, Elbir T (2014) Source apportionment of Polycyclic Aromatic Hydrocarbons (PAHs) and Polychlorinated Biphenyls (PCBs) in ambient air of an industrial region in Turkey. J Atmos Env 97:271-285

Bano S, Pervez S, Chow JC, Matawle JL, Watson JG, Sahu RK, Srivastava A, Tiwari S, Pervez YF, Deb MK (2018) Coarse particle (PM10-2.5) source profiles for emissions from domestic cooking and industrial process in Central India. J Sci Tot Env 627:1137-1145

Bouhajja E, Agathos SN, George IF (2016) Metagenomics: Probing pollutant fate in natural and engineered ecosystems. Biotechnol Adv 34(8):1413-1426. https://doi.org/ 10.1016/j.biotechadv.2016.10.006.

Brumfield KD, Huq A, Colwell RR, Olds JL, Leddy MB (2020) Microbial resolution of whole genome shotgun and 16S amplicon metagenomic sequencing using publicly available NEON data. PLoS ONE 15 (2):e0228899. https://doi.org/ 10.1371/journal.pone.0228899.

Cai Y, Mo H, Wu T, Zeng Y, Katsoyiannis A, Ferard F (2007) Bioremediation of polycyclic aromatic hydrocarbons (PAHs)-contaminated sewage sludge by different composting processes. J Hazard Mater 142 (1-2):535-542. https://doi.org /10.1016/j.jhazmat.2006.08.062.

Cheung PY, Kinkle BK (2001) Mycobacterium diversity and pyrene mineralization in petroleum-contaminated soils. Appl Environ Microbiol 67(5): 2222-2229. https://doi.org/ 10.1128/AEM.67.5.2222-2229.2001.

Cleveland CC, Liptzin D (2007) C:N:P stoichiometry in soil: is there a "Redfield ratio" for the microbial biomass? Biogeochemistry. 85:235-252. https://doi.org/10.1007/s10533-007-9132-0. 
Cummings PJ, Olszewicz J, Obom KM (2017) Nanopore DNA Sequencing for Metagenomic Soil Analysis. J Vis Exp 130:55979. doi: 10.3791/55979.

Delgado-Baquerizo M, Eldridge DJ, Ochoa V, Gozalo B, Singh BK, Maestre FT (2017) Soil microbial communities drive the resistance of ecosystem multi functionality to global change in drylands across the globe. Ecol Lett 20:1295-1305. https://doi.org/ 10.1111/ele.12826.

Devpura N, Jain K, Patel A, Joshi CG, Madamwar D (2017) Metabolic potential and taxonomic assessment of bacterial community of an environment to chronic industrial discharge. Int Biodeterior Biodegradation 123:216-227. https://doi.org/10.1016/j.ibiod.2017.06.011.

Egland PG, Gibson J, Harwood CS (1995) Benzoate-coenzyme A ligase, encoded by badA, is one of three ligases able to catalyze benzoyl-coenzyme A formation during anaerobic growth of Rhodopseudomonas palustris on benzoate. J Bacteriol 177 (22):6545-6551 https://doi.org/ 10.1128/jb.177.22.65456551.

Engraff M, Solere C, Smith KEC, Mayer P, Dahllof I (2011) Aquatic toxicity of PAHs and PAH mixtures at saturation to benthic amphi pods: linking toxic effects to chemical activity. Aquat Toxicol 102:142-149

Galazka A, Grzadziel J, Gałazka R, Ukalska-Jaruga A, Strzelecka J, Smreczak B (2018) Genetic and Functional Diversity of Bacterial Microbiome in Soils with Long Term Impacts of Petroleum Hydrocarbons. Front Microbiol 9:1923 https://doi.org/10.3389/fmicb.2018.01923.

Giachino A, Waldron KJ (2020) Copper tolerance in bacteria requires the activation of multiple accessory pathways. Mol Microbiol 114 (3):377-390. https://doi.org/10.1111/mmi.14522.

Godheja J, Shekhar SK, Satyanarayan GNV, Singh SP, Modi DR (2017) Antibiotic and heavy metal tolerance of some indigenous bacteria isolated from petroleum contaminated soil sediments with a study of their aromatic hydrocarbon degradation potential. Int J Curr Microbiol App Sci 6(3):194-211

Goris J, De Vos, P, Caballero-Mellado J, Park J, Falsen E, JF, Tiedje JM, Vandamme P (2004) Classification of the biphenyl- and polychlorinated biphenyldegrading strain $\mathrm{LB} 400^{\top}$ and relatives as Burkholderia xenovorans sp. nov. Int J Syst Evol Microbiol 54 (5): 21

Grostern A, Sales CM, Zhuang WQ, Erbilgin O, Alvarez-Cohen L (2012) Glyoxylate metabolism is a key feature of the metabolic degradation of 1,4-dioxane by Pseudonocardia dioxanivorans strain CB1190. Appl Environ Microbiol 78 (9): 3298-3308. https://doi.org/ 10.1128/AEM.00067-12.

Guarino C, Zuzolo D, Marziano M, Conte B, Baiamonte G, Morra L, Benotti D, Gresia D, Stacul E, Cicchella D, Sciarrillo R (2019) Investigation and Assessment for an effective approach to the reclamation of Polycyclic Aromatic Hydrocarbon (PAHs) contaminated site: SIN Bagnoli, Italy. Scientific Reports 9:11522. https:doi.org/ 10.1038/s41598-019-48005-7.

Harwood, CS, Parales RE (1996) The beta-ketoadipate pathway and the biology of self-identity. Annu Rev Microbiol 50:553-590. https://doi.org/ 10.1146/annurev.micro.50.1.553.

Hatamian-Zarmi A, Shojaosadati SA, Vasheghani-Farahani E, Hosseinkhani S, Emamzadeh A (2009) Extensive biodegradation of highly chlorinated biphenyls and Aroclor 1242 by Pseudomonas aeruginosa TMU56 isolated from contaminated soils. Int Biodeter Biodegr 63:788-794

He Q, Sanford RA (2003) Characterization of Fe (III) reduction by chlororespiring Anaeromyxobacter dehalogens.. Appl Environ Microbiol 69:2712-2718. https://doi.org/10.1128/AEM.69.5.2712-2718.2003.

He Z, Wang L, Peng Y, Luo M, Wang W, Liu X (2015) Determination of selected polychlorinated biphenyls in soil and earthworm (Eisenia fetida) using a QuEChERS-based method and gas chromatography with tandem MS. J Sep Sci 38 (21):3766-3773. https://doi.org/ 10.1002/jssc.201500624.

Heider J, Boll M, Breese K, et al (1998) Differential induction of enzymes involved in anaerobic metabolism of aromatic compounds in the denitrifying bacterium Thauera aromatica. Arch Microbiol 170:120-131. https://doi.org/10.1007/s002030050623.

Isaac P, Sanchez LA, Bourguignon N, Cabral ME, Ferrero MA (2013) Indigenous PAH-degrading bacteria from oil-polluted sediments in Caleta Cordova, Patagonia Argentina. Int Biodeterior Biodegradation 82:207-214. https://doi.org/10.1016/j.ibiod.2013.03.009.

Isaac P, Martinez FL, Bourguignon N, Sanchez LA, Ferrero MA (2015) Improved PAHs removal performance by a defined bacterial consortium of indigenous Pseudomonas and Actinobacteria from Patagonia, Argentina. Int Biodeterior Biodegrad 101:23-31. https://doi.org/ 10.1016/j.ibiod.2015.03.014.

Jiang L, Luo C, Zhang D, Song M, Sun Y, Zhang G (2018) Biphenyl-Metabolizing Microbial Community and a Functional Operon Revealed in E-WasteContaminated Soil. Environ Sci Technol 52 (15):8558-8567. https://doi.org/10.1021/acs.est.7b06647.

Jiun-Hornga T, Kuo-Hsiungb L, Chih-Yub C, Jian-Yuanb D, Ching-Guanb C, Hung-Lungc C (2007) Chemical constituents in particulate emissions from an integrated iron and steel facility. J Haz Mat 147:111-119. http://doi.org/10.1016/j.jhazmat.2006.12.054.

Jones KC, de P Voogt P (1998) Persistent organic pollutants (POPs): state of the science. Environ Pollut 100:209-221

Jorge LM, Rodrigues CAK, Michael RA, John FQ, Olga VM, Tamara VT, James MT (2006) Degradation of Aroclor 1242 Dechlorination Products in Sediments by Burkholderia xenovorans LB400 (ohb) and Rhodococcus sp. Strain RHA1(fcb). Appl Environ Microbiol 72 (4):2476-2482.

https://doi.org/10.1128/AEM.72.4.2476-2482.2006.

Page 9/26 
Keegan KP, Glass EM, Meyer F (2016) MG-RAST, a metagenomics service for analysis of microbial community structure and function. Methods Mol Biol 207233. https://doi.org/ 10.1007/978-1-4939-3369-3_13.

Khaparde VV, Bhanarkar AD, Majumdar D, Rao CVC (2016) Characterization of polycyclic aromatic hydrocarbons in fugitive PM10 emissions from an integrated iron and steel plant. J Sci Tot Env 562:155-163. https://doi.org/ 10.1016/j.scitotenv.2016.03.153.

Komancova M, Jurcova I, Kochankov L, Burkhard J (2003) Metabolic pathways of polychlorinated biphenyls degradation by Pseudomonas sp. 2. Chemosphere 50 (4): 537-543. https://doi.org/ 10.1016/S0045-6535(02)00374-0.

Langenhoff AAM, Zehnder AJB, Schraa G (1996) Behaviour of toluene, benzene and naphthalene under anaerobic conditions in sediment columns. Biodegradation 7:267-274. https://doi.org/ 10.1007/BF00058186.

Laver T, Harrison J, O'Neill PA, Moore K, Farbos A, Paszkiewicz K, Studholme DJ (2015) Assessing the performance of the Oxford Nanopore Technologies MinION. Biomol Detect Quantif 3:1-8. https://doi.org/ 10.1016/J.BDQ.2015.02.001.

Lovley DR, Ueki T, Zhang T, et al (2011) Geobacter: the microbe electric's physiology, ecology, and practical applications. Advances Microbial Physiology 59:1100. https://doi.org/10.1016/b978-0-12-387661-4.00004-5.

Lu C, Hong Y, Liu J, Gao Y, Ma Z, Yang B, Ling W, Waigi MG (2019) A PAH-degrading bacterial community enriched with contaminated agricultural soil and its utility for microbial bioremediation. J Env Pol 251:773-782. https://doi.org/10.1016/j.envpol.2019.05.044.

Ma Q, QuY, Shen W, et al (2015) Bacterial community compositions of coking wastewater treatment plants in steel industry revealed by Illumina highthroughput sequencing. J Bior Tech 179:436-443. https://doi.org/ 10.1016/j.biortech.2014.12.041.

Mars AE, Kasberg T, Kaschabek SR, van Agteren, MH, Janssen DB, Reineke W (1997) Microbial degradation of chloroaromatics: use of the meta-cleavage pathway for mineralization of chlorobenzene. J Bact 179:4530-4537

Mars AE, Kingma J, Kaschabek SR, Reineke W, Janssen DB (1999) Conversion of 3-chlorocatechol by various catechol 2,3-dioxygenases and sequence analysis of the chlorocatechol dioxygenase region of Pseudomonas putida GJ31. J Bact 181:1309-1319

McLeod MP, Warren RL, et al (2006) The complete genome of Rhodococcus sp. RHA1 provides insights into a catabolic powerhouse. Proc Natl Acad Sci USA 103:15582-15587

Meyer-Cifuentes I, Martinez-Lavanchy PM, Marin-Cevada V, Bohnke S, Harms H, Muller, JA, Heipieper, HJ (2017) Isolation and characterization of Magnetospirillum sp. strain 15-1 as a representative anaerobic toluene-degrader from a constructed wetland model. PLoS One. 12(4).

https://doi.org/10.1371/journal.pone.0174750.

Nicolitch O, Feucherolles M, Churin JL, et al (2019) A microcosm approach highlights the response of soil mineral weathering bacterial communities to an increase of K and Mg availability. Sci Rep 9:14403. https://doi.org/10.1038/s41598-019-50730-y.

Ontiveros-Cuadras, JF, Ruiz-Fernandez AC, Sanchez-Cabeza JA, Sericano J, Perez-Bernal LH, Paez-Osuna F, Dunbar RB, Mucciarone DA (2019) Recent history of persistent organic pollutants (PAHs, PCBs, PBDEs) in sediments from a large tropical lake. J Hazardous Mat 368, $264-273$.

https://doi.org/10.1016/j.jhazmat.2018.11.010.

Pagnout C, Frache G, Poupin P, Maunit B, Muller JF, Ferard JF (2007) Isolation and characterization of a gene cluster involved in PAH degradation in Mycobacterium sp. strain SNP11:expression in Mycobacterium smegmatis mc(2) 155. Res Microbiol 158:175-86

Parks DH, Beiko RG (2010) Identifying biologically relevant differences between metagenomic communities. Bioinformatics 26 (6):715-21

Patel KS, Ramteke S, Sahu BL, Nayak Y, Sharma S, Hung CC (2015) Polychlorinated Biphenyls Contamination of Sludge in India. AJAC 6:867-877. https://dx.doi.org/10.4236/ajac.2015.611082.

Randle-Boggis RJ, Helgason T, Sapp M, Ashton PD (2016) Evaluating techniques for metagenome annotation using simulated sequence data. FEMS Microbiol Ecol 92:95. https://doi.org/ 10.1093/femsec/fiw095.

Ribeiro H, Sousa T, Santos JP, Sousa AGG, Teixeira C, Monteiro MR, Salgado P, Mucha AP, Almeida CMR, Torgo L, Magalhaes C (2018) Potential of dissimilatory nitrate reduction pathways in polycyclic aromatic hydrocarbon degradation. Chemosphere 199:54-67

Rodrigues JL, Kachel CA, Aiello MR, Quensen JF, Maltseva OV, Tsoi TV, Tiedje JM (2006) Degradation of aroclor 1242 dechlorination products in sediments by Burkholderia xenovorans LB400 (ohb) and Rhodococcus sp. strain RHA1(fcb). Appl Environ Microbiol 72 (4):2476-82

Saavedra JM, Acevedo F, Gonzalez M, Seeger M (2010) Mineralization of PCBs by the genetically modified strain Cupriavidus necator JMS34 and its application for bioremediation of PCBs in soil. Appl Microbiol Biotechnol 87:1543-1554. https://doi.org/ 10.1007/s00253-010-2575-6.

Saito A, Iwabuchi T, Harayama S (2000) A novel phenanthrene dioxygenase from Nocardioides sp. strain KP7: expression in Escherichia coli. J Bacteriol 182:2134-2141 
Samson R, Shah M, Yadav R, Sarode P, Rajput V, Dastager SG, Dharne MS, Khairnar K (2019) Metagenomic insights to understand transient influence of Yamuna River on taxonomic and functional aspects of bacterial and archaeal communities of River Ganges. J Sci Tot Env 674:288-299.

https://doi.org/10.1016/j.scitotenv.2019.04.166.

Seo JS, Keum YS, Li QX (2009) Bacterial degradation of aromatic compounds. Int J Environ Res Public Health 6 (1):278-309.

https://doi.org/10.3390/ijerph6010278.

Singh DP, Prabha R, Gupta VK, Verma MK (2018) Metatranscriptome analysis deciphers multifunctional genes and enzymes linked with the degradation of aromatic compounds and pesticides in the wheat rhizosphere. Front Microbiol 9:1331. https://doi.org/10.3389/fmicb.2018.01331.

Stanford RA, Cole JR, Tiedje JM (2002) Characterization and Description of Anaeromyxobacter dehalogenans gen. nov., sp. nov., an Aryl-Halorespiring Facultative Anaerobic Myxobacterium. Appl Environ Microbiol 68 (2):893-900. https://doi.org/ 10.1128/AEM.68.2.893-900.2002.

Su XM, Liu YD, Hashmi MZ, Ding LX, Shen CF (2015) Culture-dependent and culture-independent characterization of potentially functional biphenyl-degrading bacterial community in response to extracellular organic matter from Micrococcus luteus. Microb Biotechnol 8 (3): 569-578. https://doi.org/10.1111/17517915.12266

Valderrama JA, Durante-Rodriguez G, Blazquez B, Garcia JL, Carmona M, Díaz E (2012) Bacterial Degradation of Benzoate cross-regulation between aerobic and anaerobic pathways. J Biol Chem 287 (13):10494 -10508

Van Gerven T, Geysen D, Vandecasteele C (2004) Estimation of the contribution of a municipal waste incinerator to the overall emission and human intake of PCBs in Wilrijk,Flanders.Chemosphere 54:1303-1308.https://doi.org/10.1016/S0045-6535(03)00233-9.

Vila J, Nieto M, Mertens J, Springael D, Grifoll M (2010) Microbial community structure of a heavy fuel oil-degrading marine consortium, linking microbial dynamics with polycyclic aromatic hydrocarbon utilization. FEMS Microbiol Ecol 73:349-362

Vinas M, Sabate J, Espuny MJ, Solanas AM (2005) Bacterial Community Dynamics and Polycyclic Aromatic Hydrocarbon Degradation during Bioremediation of Heavily Creosote-Contaminated Soil. Appl Environ Microbiol 7008-7018. https://doi.org/ 10.1128/AEM.71.11.7008-7018.2005.

Weiland-Brauer N, Fischer MA, Schramm KW, Schmitz RA (2017) Polychlorinated Biphenyl (PCB)-Degrading Potential of Microbes Present in a Cryoconite of Jamtalferner Glacier. Front Microbiol 8:1105. https://doi.org/10.3389/fmicb.2017.01105.

Wittich RM, Strompl C, Moore ERB, Blasco R, Timmis KN (1999) Interactions of Sphingomonas and Pseudomonas strains in the degradation of chlorinated dibenzofurans. J Ind Microbiol Biotechnol 23:353-358

Yang HH, Lai SO, Hsieh LT, Hsueh HJ, Chi TW (2002) Profiles of PAH emission from steel and iron industries. Chemosphere 48: 1061-1074

Yang X, Liu X, Song L, Xie F, Zhang G, Qian S (2007) Characterization and functional analysis of a novel gene cluster involved in biphenyl degradation in Rhodococcus sp. strain R04. J Appl Microbiol 103:2214-2224. https://doi.org/ 10.1111/j.1365-2672.2007.03461.x

Zhang De-C, Mortelmaier C, Margesin R (2012) Characterization of the bacterial archaeal diversity in hydrocarbon-contaminated soil. Sci Tot Environ 421422:184-196. https://doi.org/10.1016/j.scitotenv.2012.01.043.

Zhang W, Wei C, An G (2015) Distribution, partition and removal of polycyclic aromatic hydrocarbons (PAHs) during coking wastewater treatment processes. Environ Sci Process Impacts 17 (5):975-984

Zhang S, Hu Z, Wang H (2019) Metagenomic analysis exhibited the co-metabolism of polycyclic aromatic hydrocarbons by bacterial community from estuarine sediment. Environ Int 129:308-319

\section{Tables}

Table 1 Physio chemical parameters of the contaminated soil sample MGB-2 and MGB-3 from polluted near Bhilai steel plant

Table 2 Alpha diversity for bacterial, archaea and eukaryota communities of collected soil from polluted site near

Bhilai steel plant 


\begin{tabular}{|c|c|c|c|}
\hline Soil testing parameter & MGB-2 & MGB-3 & Reference value \\
\hline $\mathrm{pH}$ & 7.83 & 7.69 & V. acidic $<5.0$, Acidic $5.0<6.0$, Normal $6.0-8.0$, Alkaline $8.0<9.0$ \\
\hline Electrical Conductivity (dSm-1) & 0.21 & 0.183 & $<1.0$ Normal \\
\hline Organic Carbon (\%) & 0.85 & 1.39 & $<0.5$ Low, 0.50 - 0.75 Medium, $>0.75$ - High \\
\hline Nitrogen (kg ha-1) & 430 & 734 & $<280$ Low, 281 - 560 Medium, > 560 High \\
\hline Phosphorous(kg ha-1) & 17.66 & 56.9 & $<22$ Low, 23 - 56 Medium, > 56 High \\
\hline Potassium(kg ha-1) & 1232 & 336 & $<112$ Low, 113 - 280 Medium, > 280 High \\
\hline Calcium Carbonate (\%) & 7.2 & 7.6 & $<1$ Low, 1 - 5 Normal, 5-10 Sufficient, > 10 Harmful \\
\hline Available Calcium (ppm) & 640 & 960 & $<500$ Low, $500-1000$ Normal, >1000 Sufficient \\
\hline Magnesium (ppm) & 768 & 576 & $<250$ Low, 250 - 500 Normal, >500 Sufficient \\
\hline Available Sodium (ppm) & 138 & 126.5 & Up to 400 Normal, 400 - 700 Problem may occur, > 700 Harmful \\
\hline Chloride (ppm) & 11.92 & 7.95 & Up to 350 Normal, 350 - 1050 Slightly problem, > 1050 Harmful \\
\hline Sulphur (mgkg-1) & 16.37 & 25.37 & $<10$ Low, $10-50$ Normal, 50 High \\
\hline Zinc (mgkg-1) & 1.218 & 3.267 & $<0.6$ Low, 0.61- 5.0Medium, >5.1 High \\
\hline Iron (mgkg-1) & 8.372 & 14.98 & < 4.5 Low, 4.6 -24 Medium, >25 High \\
\hline Copper (mgkg-1) & 1.286 & 1.575 & $<0.2$ Low, $0.3-1.5$ Medium, >1.5 High \\
\hline Manganese (mgkg-1) & 44.12 & 17.44 & $<2.0$ Low, 2.1 - 29 Medium, >30 High \\
\hline Water Holding Capacity (\%) & 46 & 43.81 & $<20$ Low, $20-50$ Medium, > 50 High \\
\hline
\end{tabular}

\begin{tabular}{|lllllllll|}
\hline Domain & Bacteria & \multicolumn{3}{c}{ Archaea } & \multicolumn{3}{c|}{ Eukaryota } & \multicolumn{2}{c|}{ Total Diversity } \\
\hline Sample & MGB-2 & MGB-3 & MGB-2 & MGB-3 & MGB-2 & MGB-3 & MGB-2 & MGB-3 \\
\hline Simpson_1-D & 0.9957 & 0.9964 & 0.9788 & 0.9798 & 0.9847 & 0.987 & 0.9959 & 0.9966 \\
\hline Shannon_H & 6.175 & 6.25 & 4.12 & 4.139 & 4.638 & 4.743 & 6.267 & 6.341 \\
\hline Evenness_e^H/S & 0.3456 & 0.3689 & 0.7075 & 0.7298 & 0.4921 & 0.5338 & 0.3057 & 0.3232 \\
\hline Brillouin & 6.155 & 6.23 & 4.03 & 4.034 & 4.492 & 4.614 & 6.244 & 6.318 \\
\hline Menhinick & 3.247 & 3.168 & 1.849 & 2.024 & 4.17 & 3.856 & 3.972 & 3.91 \\
\hline Margalef & 114.7 & 115.1 & 11.17 & 11.34 & 26.66 & 26.61 & 141.9 & 143.6 \\
\hline Equitability_J & 0.8532 & 0.8624 & 0.9225 & 0.9293 & 0.8674 & 0.8831 & 0.841 & 0.8488 \\
\hline Fisher_alpha & 204.5 & 204.4 & 18.06 & 18.8 & 54.35 & 52.45 & 262 & 264.4 \\
\hline Berger-Parker & 0.02676 & 0.0224 & 0.05917 & 0.04873 & 0.04574 & 0.04471 & 0.02608 & 0.02184 \\
\hline Chao-1 & 1414 & 1429 & 87 & 86.33 & 266 & 267.1 & 1839 & 1884 \\
\hline
\end{tabular}

Table 3 Annotated gene and enzyme identified in metagenome MGB-2 and MGB-3

a. methane metabolism 


\begin{tabular}{|c|c|c|c|}
\hline Metabolism & sublevel 3 & gene & Enzyme identified \\
\hline \multirow[t]{18}{*}{ Methane } & coenzyme M biosynthesis & comE & Sulfopyruvate decarboxylase - beta subunit [EC 4.1.1.79] \\
\hline & coenzyme $\mathrm{M}$ biosynthesis & comA & Phosphosulfolactate synthase [EC 4.4.1.19] \\
\hline & Hydrogenases & hoxF & NAD-reducing hydrogenase subunit HoxF [EC 1.12.1.2] \\
\hline & Hydrogenases & hoxY & NAD-reducing hydrogenase subunit HoxY [EC 1.12.1.2] \\
\hline & CO Dehydrogenase & cutt & Carbon monoxide dehydrogenase form I, large chain [EC 1.2.99.2] \\
\hline & H2:CoM-S-S-HTP oxidoreductase & hdrA & CoB-CoM heterodisulfide reductase subunit A [EC 1.8.98.1] \\
\hline & CO Dehydrogenase & $\operatorname{coxS}$ & Carbon monoxide dehydrogenase small chain [EC 1.2.99.2] \\
\hline & Hydrogenases & hoxh & NAD-reducing hydrogenase subunit HoxH [EC 1.12.1.2] \\
\hline & CBSS-314269.3.peg.1840 & $\operatorname{coxL}$ & Carbon monoxide dehydrogenase large chain [EC 1.2.99.2] \\
\hline & CBSS-314269.3.peg.1840 & $\operatorname{coxM}$ & Carbon monoxide dehydrogenase medium chain [EC 1.2.99.2] \\
\hline & Methanogenesis from methylated & $m t t \mathrm{~B}$ & Trimethylamine:corrinoid methyltransferase [EC 2.1.1.250] \\
\hline & Methanogenesis & hdre2 & CoB-CoM heterodisulfide reductase subunit C [EC 1.8.98.1] \\
\hline & Serine-glyoxylate cycle & $m c H$ & 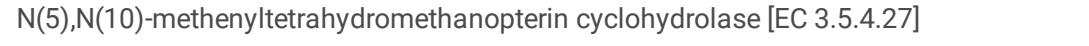 \\
\hline & Methanogenesis & fhcD & Formylmethanofuran-tetrahydromethanopterin $\mathrm{N}$-formyltransferase [EC 2.3.1.101] \\
\hline & One-carbon by tetrahydropterines & $m t d \mathrm{C}$ & Methylene tetrahydromethanopterin dehydrogenase [EC 1.5.99.9] \\
\hline & Methanogenesis & $f w d \mathrm{~A}$ & Formylmethanofuran dehydrogenase subunit A [EC 1.2.99.5] \\
\hline & Methanogenesis & fno & F420-dependent $\mathrm{N}(5), \mathrm{N}(10)$-methylenetetrahydromethanopterin reductase [EC 1.5.99.11] \\
\hline & Methanogenesis & $f w d \mathrm{~B}$ & Formylmethanofuran dehydrogenase subunit B [EC 1.2.99.5] \\
\hline
\end{tabular}

b-c. Nitrogen and Sulfur metabolism

Table 4. Annotated enzyme and the assigned genera in metagenome MGB-2 and MGB-3

a. Chlorocyclohexane and chlorobenzene degradation pathway 


\begin{tabular}{|c|c|c|c|}
\hline Metabolism & sublevel 3 & gene & Enzyme identified \\
\hline \multirow[t]{19}{*}{ Nitrogen } & Denitrification & nirs & Cytochrome cd1 nitrite reductase [EC 1.7.2.1] \\
\hline & Denitrification & nirk & Copper-containing nitrite reductase [EC 1.7.2.1] \\
\hline & Denitrification & norB & Nitric-oxide reductase subunit B [EC 1.7.99.7] \\
\hline & Denitrification & norC & Nitric-oxide reductase subunit C [EC 1.7.99.7] \\
\hline & Denitrification & nosZ & Nitrous-oxide reductase [EC 1.7.99.6] \\
\hline & Denitrification & norD & Nitric oxide reductase activation protein NorD \\
\hline & Denitrification & norQ & Nitric oxide reductase activation protein NorQ \\
\hline & Denitrification & qnor & Nitric-oxide reductase, quinol-dependent [EC 1.7.99.7] \\
\hline & Nitrate and nitrite ammonification & nitH & Polyferredoxin $\mathrm{NapH}$ (periplasmic nitrate reductase) \\
\hline & Nitrate and nitrite ammonification & nirB & Assimilatory nitrate reductase large subunit [EC:1.7.99.4] \\
\hline & Nitrate and nitrite ammonification & nitH & Nitrite reductase $[\mathrm{NAD}(\mathrm{P}) \mathrm{H}]$ small subunit [EC 1.7.1.4] \\
\hline & Nitrate and nitrite ammonification & nosZ & Ferredoxin--nitrite reductase [EC 1.7.7.1] \\
\hline & Nitrate and nitrite ammonification & $n r f E$ & Cytochrome c-type heme lyase subunit nrfE [EC 4.4.1.-] \\
\hline & Nitrate and nitrite ammonification & napB & Nitrate reductase cytochrome c550-type subunit [EC 1.9.6.1] \\
\hline & Nitrate and nitrite ammonification & nitH & Nitrite reductase $[\mathrm{NAD}(\mathrm{P}) \mathrm{H}]$ large subunit [EC 1.7.1.4] \\
\hline & Nitrate and nitrite ammonification & napA & Periplasmic nitrate reductase precursor [EC 1.7.99.4] \\
\hline & Nitrogen fixation & nifN & Nitrogenase FeMo-cofactor scaffold and assembly protein NifN [EC 1.18.6.1] \\
\hline & Nitrogen fixation & nifE & Nitrogenase FeMo-cofactor scaffold and assembly protein NifE[ EC 1.18.6.1] \\
\hline & Nitrogen fixation & nifK & Nitrogenase (molybdenum-iron) beta chain [EC 1.18.6.1] \\
\hline \multirow[t]{6}{*}{ Sulfur } & Inorganic Sulfur Assimilation & cysN & Sulfate adenylyltransferase, dissimilatory-type [EC 2.7.7.4] \\
\hline & Inorganic Sulfur Assimilation & cysH & Phosphoadenylyl-sulfate reductase [thioredoxin] [EC 1.8.4.8] \\
\hline & Inorganic Sulfur Assimilation & $\operatorname{siR}$ & Ferredoxin-sulfite reductase [EC 1.8.7.1] \\
\hline & Inorganic Sulfur Assimilation & papsR & Adenylyl-sulfate reductase [thioredoxin] [EC 1.8.4.10] \\
\hline & Inorganic Sulfur Assimilation & cysC & Adenylylsulfate kinase [EC 2.7.1.25] \\
\hline & Inorganic Sulfur Assimilation & cysl & Sulfite reductase [NADPH] hemoprotein beta-component [EC 1.8.1.2] \\
\hline
\end{tabular}




\begin{tabular}{|c|c|c|c|c|}
\hline Pathway & Gene & Anotated Enzyme & Assigned bacteria in MGB-2 & Assigned bacteria in MGB-3 \\
\hline \multirow{12}{*}{$\begin{array}{l}\text { Chlorocyclohexane } \\
\text { and chlorobenzene } \\
\text { degradation } \\
\text { [PATH:ko00361] }\end{array}$} & chqB & $\begin{array}{l}\text { hydroxyquinol 1,2-dioxygenase } \\
\text { [EC:1.13.11.37] }\end{array}$ & $\begin{array}{l}\text { Arthrobacter, Bradyrhizobium } \\
\text { Burkholderia, Cupriavidus } \\
\text { Variovorax, Verminephrobacter }\end{array}$ & $\begin{array}{l}\text { Catenulispora } \\
\text { Bradyrhizobium }\end{array}$ \\
\hline & pсpB & $\begin{array}{l}\text { pentachlorophenol } \\
\text { monooxygenase } \\
\text { [EC:1.14.13.50] }\end{array}$ & Rhodococcus & Anabaena, Burkholderia \\
\hline & pheA & $\begin{array}{c}\text { phenol 2-monooxygenase } \\
\text { [EC:1.14.13.7] }\end{array}$ & $\begin{array}{l}\text { Arthrobacter, Bradyrhizobium, } \\
\text { Nocardia, Renibacterium, } \\
\text { Rhodococcus, Rubrobacter }\end{array}$ & $\begin{array}{l}\text { Agrobacterium, Arthrobacter, Azoarcus, } \\
\text { Bradyrhizobium, Methylobacterium, } \\
\text { Nocardia, Paracoccus, Rhodococcus, } \\
\text { Rubrobacter }\end{array}$ \\
\hline & $\mathrm{pnpD}$ & $\begin{array}{c}\text { maleylacetate reductase } \\
\text { [EC:1.3.1.32] }\end{array}$ & Bradyrhizobium, Polaromonas & $\begin{array}{l}\text { Bradyrhizobium, Burkholderia, } \\
\text { Polaromonas, Rhodococcus, } \\
\text { Rhodopseudomonas }\end{array}$ \\
\hline & clcD & $\begin{array}{c}\text { carboxymethylenebutenolidase } \\
\text { [EC:3.1.1.45] }\end{array}$ & $\begin{array}{l}\text { Acidimicrobium, Agrobacterium, } \\
\text { Arthrobacter, Azoarcus, } \\
\text { Bradyrhizobium, Burkholderia, } \\
\text { Candidatus, Cupriavidus, } \\
\text { Desulfobacterium, Gemmatimonas, } \\
\text { Methanoculleus, Polaromonas, } \\
\text { Pseudomonas, Rhodococcus, } \\
\text { Rhodopseudomonas, Sphingobium }\end{array}$ & $\begin{array}{l}\text { Acetobacter, Acidimicrobium, } \\
\text { Acidobacterium, Agrobacterium, } \\
\text { Azoarcus, Beijerinckia, Bradyrhizobium, } \\
\text { Burkholderia, Candidatus, Cellvibrio, } \\
\text { Cupriavidus, Dechloromonas, } \\
\text { Desulfobacterium,,Flavobacterium, } \\
\text { Gemmatimonas, Polaromonas, } \\
\text { Rhodococcus, Sphingomonas }\end{array}$ \\
\hline & hadL & $\begin{array}{c}\text { 2-haloacid dehalogenase } \\
\text { [EC:3.8.1.2] }\end{array}$ & $\begin{array}{l}\text { Beijerinckia, Bordetella, Burkholderia, } \\
\text { Cupriavidus, Methylobacterium, } \\
\text { Mycobacterium, Oligotropha, } \\
\text { Rhodopseudomonas }\end{array}$ & $\begin{array}{l}\text { Acidovorax, Anaeromyxobacter, } \\
\text { Beijerinckia, Bordetella, Bradyrhizobium, } \\
\text { Burkholderia, Candidatus, } \\
\text { Chromobacterium, Mesorhizobium, } \\
\text { Methylobacterium, Mycobacterium, } \\
\text { Methylocella, Polaromonas, } \\
\text { Rhodopseudomonas, Sorangium, } \\
\text { Xanthomonas }\end{array}$ \\
\hline & dehH & $\begin{array}{l}\text { haloacetate dehalogenase } \\
\text { [EC:3.8.1.3] }\end{array}$ & $\begin{array}{l}\text { Anabaena, Anaeromyxobacter, } \\
\text { Azoarcus, Burkholderia, Chloroflexus, } \\
\text { Cupriavidus, Kribbella, } \\
\text { Mesorhizobium, Methylobacterium, } \\
\text { Nocardiopsis, Micromonospora } \\
\text { Psychromonas, Rhizobium, } \\
\text { Rhodopseudomonas, Roseiflexus, } \\
\text { Saccharopolyspora }\end{array}$ & $\begin{array}{l}\text { Anabaena, Anaeromyxobacter, } \\
\text { Bradyrhizobium, Burkholderia, } \\
\text { Chloroflexus, Geodermatophilus,, } \\
\text { Mesorhizobium, Methylibium, } \\
\text { Methylobacterium, Nocardiopsis, } \\
\text { Psychromonas, Rhodopseudomonas, } \\
\text { Roseiflexus, }\end{array}$ \\
\hline & bedC1 todC1 & $\begin{array}{l}\text { benzene/toluene dioxygenase } \\
\text { subunit alpha } \\
\text { [EC:1.14.12.3 1.14.12.11] }\end{array}$ & Mycobacterium & Mycobacterium \\
\hline & bphC & $\begin{array}{l}\text { biphenyl-2,3-diol 1,2- } \\
\text { dioxygenase } \\
\quad[\text { EC:1.13.11.39] }\end{array}$ & Rhizobium & $\begin{array}{l}\text { Mycobacterium, Candidatus, } \\
\text { Bradyrhizobium }\end{array}$ \\
\hline & catA & $\begin{array}{c}\text { catechol 1,2-dioxygenase } \\
{[\mathrm{EC}: 1.13 .11 .1]}\end{array}$ & $\begin{array}{l}\text { Cupriavidus, Methylobacterium, } \\
\text { Pseudomonas, Sphingobium, } \\
\text { Streptomyces }\end{array}$ & $\begin{array}{l}\text { Azospirillum, Bradyrhizobium, } \\
\text { Burkholderia, Delftia, Mycobacterium, } \\
\text { Pseudomonas, Rhizobium, } \\
\text { Sphingomonas, }\end{array}$ \\
\hline & catB & $\begin{array}{l}\text { muconate cycloisomerase } \\
\text { [EC:5.5.1.1] }\end{array}$ & Rhodopirellula & Mycobacterium \\
\hline & $\mathrm{dmpB}$ & $\begin{array}{c}\text { catechol 2,3-dioxygenase } \\
{[\text { EC:1.13.11.2] }}\end{array}$ & $\begin{array}{l}\text { Arthrobacter, Bradyrhizobium, } \\
\text { Brucella, Geobacillus, Meiothermus, } \\
\text { Rubrobacter }\end{array}$ & $\begin{array}{l}\text { Agrobacterium, Bradyrhizobium, } \\
\text { Burkholderia, Meiothermus, } \\
\text { Methylibium, Rhodococcus, }\end{array}$ \\
\hline
\end{tabular}

b. Biphenyl/ PAH degrading pathway 


\begin{tabular}{|c|c|c|c|c|}
\hline Pathway & Gene & Annotated Enzymes & Assigned bacteria in MBG-2 & Assigned bacteria in MBG-3 \\
\hline \multirow[t]{6}{*}{$\begin{array}{l}\text { Biphenyl } \\
\text { degradation }\end{array}$} & bphA & $\begin{array}{l}\text { biphenyl 2,3-dioxygenase } \\
\text { [EC:1.14.12.18] }\end{array}$ & $\begin{array}{l}\text { Mycobacterium vanbaalenii } \\
\text { PYR-1 }\end{array}$ & $\begin{array}{l}\text { Mycobacterium vanbaalenii PYR-1, Polaromonas } \\
\text { naphthalenivorans CJ2 }\end{array}$ \\
\hline & $b p h \mathrm{~B}$ & $\begin{array}{l}\text { cis-2,3-dihydrobiphenyl-2,3- } \\
\text { diol dehydrogenase [EC } \\
1.3 .1 .56]\end{array}$ & nd & nd \\
\hline & bphC & $\begin{array}{l}\text { biphenyl-2,3-diol 1,2- } \\
\text { dioxygenase [EC:1.13.11.39] }\end{array}$ & $\begin{array}{l}\text { Mycobacterium } \\
\text { smegmatis str. MC2 } 155\end{array}$ & $\begin{array}{l}\text { Alkalilimnicola ehrlichii MLHE-1, Mycobacterium smegmatis } \\
\text { str. MC2 155, Mycobacterium tuberculosis KZN 1435, } \\
\text { Mycobacterium bovis BCG str. Tokyo } 172\end{array}$ \\
\hline & $b p h \mathrm{D}$ & $\begin{array}{l}\text { 2,6-dioxo-6-phenylhexa-3- } \\
\text { enoate hydrolase [EC:3.7.1.8] }\end{array}$ & Nocardioides sp. JS614 & Mycobacterium marinum M, Polynucleobacter necessaries, \\
\hline & $b p h \mathrm{E}$ & $\begin{array}{l}\text { 2-hydroxypenta-2,4-dienoate } \\
\text { hydratase [EC 4.2.1.80] }\end{array}$ & nd & Polynucleobacter necessarius \\
\hline & $b p h \mathrm{~F}$ & $\begin{array}{l}\text { 4-hydroxy-2-oxovalerate } \\
\text { aldolase [EC 4.1.3.39] }\end{array}$ & $\begin{array}{l}\text { Carboxydothermus } \\
\text { hydrogenoformans, } \\
\text { Pseudomonas putida F1, } \\
383 \quad \text { Burkholderia sp. } \\
\end{array}$ & 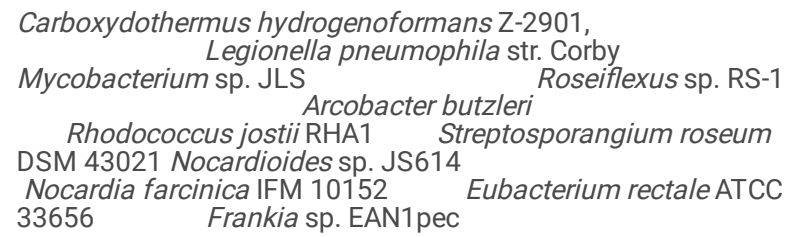 \\
\hline
\end{tabular}

\begin{tabular}{|c|c|c|c|}
\hline $\begin{array}{l}\text { PAH } \\
\text { degradation }\end{array}$ & $n a h D$ & $\begin{array}{l}\text { hydroxychromene-2- } \\
\text { carboxylate isomerase } \\
\text { [EC:5.99.1.4] }\end{array}$ & $\begin{array}{l}\text { Agrobacterium tumefaciens, } \\
\text { Aromatoleum aromaticum, } \\
\text { Bradyrhizobium sp. BTAi1, } \\
\text { Dechloromonas } \\
\text { aromatic, Pseudoalteromonas } \\
\text { atlantica }\end{array}$ \\
\hline
\end{tabular}

Aromatoleum aromaticum,

Bradyrhizobium sp. BTAi,

Burkholderia xenovorans, Parvibaculum lavamentivorans, Rhizobium leguminosarum, Ruegeria pomeroyi

nd

naphthalene dioxygenase Mesorhizobium loti

nahAc erredoxin [EC:1.14.12.12]

salicylate hydroxylase [EC:1.14.13.172]

nahG

PAH dioxygenase large subunit [EC:1.13.11.-]

PAH dioxygenase small nidA subunit [EC:1.13.11.-]

aldehyde dehydrogenase [EC:1.2.1.-]

$\operatorname{nid} B$

extradiol dioxygenase [EC:1.13.11.]

nidD hydratase-aldolase [EC:4.1.2.]

1-hydroxy-2-naphthoate phdF dioxygenase [EC:1.13.11.38]

4-(2-carboxyphenyl)-2 oxobut-3-enoate aldolase

phdG [EC:4.1.2.34]
Anaeromyxobacter dehalogenans, Burkholderia cenocepacia, Dyadobacter fermentans

Methylobacterium

extorquens, Mycobacterium smegmatis, Polaromonas

sp. JS666,

Pseudoalteromonas atlantica

nd

nd

Mycobacterium vanbaalenii

nd

nd

Mycobacterium vanbaalenii

Mycobacterium sp. KMS,

Mycobacterium sp. MCS

phdl

Acidovorax citrulli, Bordetella bronchiseptica, Corynebacterium efficiens, Cupriavidus pinatubonensis, Delftia acidovorans, Polaromonas sp. JS666, Streptomyces coelicolor

Mycobacterium sp. JLS

Mycobacterium sp. JLS

Mycobacterium vanbaalenii

Mycobacterium vanbaalenii

Mycobacterium sp. KMS

Mycobacterium vanbaalenii

Mycobacterium sp. MCS 
c. benzoate degradation via benzoyl coA, protocatechuate and catechol pathways 


\begin{tabular}{|c|c|c|c|c|}
\hline Pathway & Gene & Annotated Enzymes & Assigned bacteria in MBG-2 & Assigned bacteria in MBG-3 \\
\hline \multirow[t]{23}{*}{$\begin{array}{l}\text { Benzoate } \\
\text { degradation }\end{array}$} & ben $\mathrm{B} / \mathrm{xy} \mathrm{N}$ & $\begin{array}{l}\text { benzoate/toulene } 1,2 \text { dioxygenase } \\
\text { beta subunit }\end{array}$ & Rhodopseudomonas,Rhodococcus & Geodermatophilus, Saccharc \\
\hline & ben $\mathrm{C} / x y I Z$ & $\begin{array}{l}\text { benzoate/toulene } 1,2 \text { dioxygenase } \\
\text { electron transfer component }\end{array}$ & nd & $\begin{array}{l}\text { Geodermatophilus, Mycobac } \\
\text { Saccharopolyspora }\end{array}$ \\
\hline & \multirow{2}{*}{$\begin{array}{l}\text { benD/ } \\
\text { DHBD }\end{array}$} & \multirow{2}{*}{$\begin{array}{l}\text { 2,3-dihydroxybenzoate decarboxylase } \\
\text { [EC:4.1.1.46] }\end{array}$} & Burkholderia, & \multirow{2}{*}{$\begin{array}{l}\text { Bordetella, Novosphingobiur } \\
\text { Polaromonas, Rhizobium, } \\
\text { Rhodopseudomonas, Xanth }\end{array}$} \\
\hline & & & Rhodococcus, Rhodopseudomonas & \\
\hline & pimc & $\begin{array}{l}\text { pimeloyl-CoA dehydrogenase } \\
\text { [EC:1.3.1.62] }\end{array}$ & Cupriavidus & Cupriavidus \\
\hline & praC & $\begin{array}{l}\text { 4-oxalocrotonate tautomerase } \\
\text { [EC:5.3.2.] }\end{array}$ & nd & Candidatus, Methylocella \\
\hline & aliA & $\begin{array}{l}\text { cyclohexanecarboxylate-CoA ligase } \\
\text { [EC:6.2.1.-] }\end{array}$ & nd & $\begin{array}{l}\text { Conexibacter, Cupriavidus, } \\
\text { Rhodopseudomonas, Vermiı }\end{array}$ \\
\hline & badA & benzoate-CoA ligase [EC:6.2.1.25] & $\begin{array}{l}\text { Achromobacter, Aromatoleum, Azoarcus, } \\
\text { Burkholderia, Comamonas, Cupriavidus, Delftia }\end{array}$ & $\begin{array}{l}\text { Albidiferax , Amycolatopsis, } \\
\text { Azoarcus, Bradyrhizobium, C } \\
\text { Leptothrix, Rhodomicrobium }\end{array}$ \\
\hline & badD & $\begin{array}{l}\text { benzoyl-CoA reductase subunit } \\
\text { [EC:1.3.7.8] }\end{array}$ & Rhodopseudomonas, Thauera & Rhodopseudomonas \\
\hline & badE & $\begin{array}{l}\text { benzoyl-CoA reductase subunit } \\
\text { [EC:1.3.7.8] }\end{array}$ & Magnetospirillum, Rhodomicrobium & nd \\
\hline & badF & $\begin{array}{l}\text { benzoyl-CoA reductase subunit } \\
\text { [EC:1.3.7.8] }\end{array}$ & $\begin{array}{l}\text { Magnetospirillum, Rhodomicrobium, } \\
\text { Rhodopseudomonas, Thauera }\end{array}$ & Magnetospirillum, Rhodomi \\
\hline & badH & $\begin{array}{l}\text { 2-hydroxycyclohexanecarboxyl-CoA } \\
\text { dehydrogenase [EC:1.1.1.-] }\end{array}$ & Cupriavidus, Magnetospirillum, Nocardioides & $\begin{array}{l}\text { Alicyclobacillus, Aromatoleu } \\
\text { Rhodopseudomonas }\end{array}$ \\
\hline & badl & $\begin{array}{l}\text { 2-ketocyclohexanecarboxyl-CoA } \\
\text { hydrolase [EC:3.1.2.] }\end{array}$ & $N d$ & $\begin{array}{l}\text { Cupriavidus, Leptothrix , Poli } \\
\text { Xanthobacter }\end{array}$ \\
\hline & $h b a \mathrm{~A}$ & $\begin{array}{l}\text { 4-hydroxybenzoate-CoA ligase } \\
\text { [EC:6.2.1.27 6.2.1.25] }\end{array}$ & $\begin{array}{l}\text { Bradyrhizobium, Magnetospirillum, } \\
\text { Rhodopseudomonas }\end{array}$ & Bradyrhizobium \\
\hline & $\begin{array}{l}\text { hbaB, } \\
h c r c\end{array}$ & $\begin{array}{l}\text { 4-hydroxybenzoyl-CoA reductase } \\
\text { subunit gamma [EC:1.3.7.9] }\end{array}$ & Magnetospirillum, Rhodopseudomonas & nd \\
\hline & $\begin{array}{l}\text { hbaC, } \\
\text { hcrA }\end{array}$ & $\begin{array}{l}\text { 4-hydroxybenzoyl-CoA reductase } \\
\text { subunit alpha [EC:1.3.7.9] }\end{array}$ & Rhodopseudomonas, Thauera & nd \\
\hline & $\operatorname{lig} \mathrm{AB}$ & $\begin{array}{l}\text { protocatechuate 4,5-dioxygenase } \\
\text { [EC 1.13.11.8] }\end{array}$ & $\begin{array}{l}\text { Rhodopseudomonas, Acidimicrobium, Burkholderia, } \\
\text { Nakamurella, Novosphingobium, } \\
\text { Pseudoalteromonas, Xanthomonas }\end{array}$ & $\begin{array}{l}\text { Brevundimonas, Azoar } \\
\text { Brevundimonas, Marinomol } \\
\text { Saccharomonospora }\end{array}$ \\
\hline & $\operatorname{ligC}$ & $\begin{array}{l}\text { 2-hydroxy-4-carboxymuconate } \\
\text { semialdehyde hemiacetal } \\
\text { dehydrogenase [EC 1.1.1.312] }\end{array}$ & Rhodopseudomonas & Brevundimonas \\
\hline & $|i g|$ & $\begin{array}{l}\text { 2-pyrone-4,6-dicarboxylate lactonase } \\
\text { [EC:3.1.1.57] }\end{array}$ & $\begin{array}{l}\text { Agrobacterium, Albidiferax, Arthrobacter, } \\
\text { Bradyrhizobium, Novosphingobium, } \\
\text { Rhodopseudomonas }\end{array}$ & $\begin{array}{l}\text { Agrobacterium, Arthrobacter, } \\
\text { Bradyrhizobium, Delftia, Pol: } \\
\text { Rhodopseudomonas }\end{array}$ \\
\hline & ligJ & $\begin{array}{l}\text { 4-oxalomesaconate hydratase } \\
\text { [EC 4.2.1.83] }\end{array}$ & $\begin{array}{l}\text { Arthrobacter, Asticcacaulis, Bradyrhizobium, } \\
\text { Brevundimonas, Burkholderia, Cupriavidus, } \\
\text { Burkholderia, Methylobacterium, Paracoccus, } \\
\text { Pseudoalteromonas, Ralstonia, Rhizobium, } \\
\text { Rhodopseudomonas, Sphingobium, Variovorax, } \\
\text { Xanthomonas }\end{array}$ & $\begin{array}{l}\text { Azoarcus, Brevundimonas, E } \\
\text { Magnetospirillum,Methylobć } \\
\text { Novosphingobium, Paracocı } \\
\text { Polaromonas, Rhizobium, } \\
\text { RhodopseudomonasVermin } \\
\text { Xanthomonas }\end{array}$ \\
\hline & pobA & $\begin{array}{l}\text { p-hydroxybenzoate 3-monooxygenase } \\
\text { [EC:1.14.13.2] }\end{array}$ & $\begin{array}{l}\text { Amycolatopsis, Arthrobacter, Bacillus, Burkholderia, } \\
\text { Candidatus, Caulobacter, Chelativorans Delftia, } \\
\text { Frankia, Herbaspirillum, Mesorhizobium, } \\
\text { Novosphingobium, Rhodopseudomonas, } \\
\text { Sphaerobacter, Streptosporangium }\end{array}$ & $\begin{array}{l}\text { Agrobacterium, Amycolatop: } \\
\text { Arthrobacter, Burkholderia, C } \\
\text { Magnetospirillum, Pseudom } \\
\text { Rhodopseudomonas, } \\
\text { Saccharomonospora, Xanthı } \\
\text { Verminephrobacter }\end{array}$ \\
\hline & $p c a G$ & $\begin{array}{l}\text { beta-Carboxy-cis,cis-muconate } \\
\text { [EC:1.13.11.3] }\end{array}$ & $\begin{array}{l}\text { Bradyrhizobium, Candidatus, Cupriavidus, } \\
\text { Geodermatophilus, Sphaerobacter, Sphingomonas }\end{array}$ & Candidatus \\
\hline & pcaH & $\begin{array}{l}\text { protocatechuate 3,4-dioxygenase, beta } \\
\text { subunit [EC:1.13.11.3] }\end{array}$ & $\begin{array}{l}\text { Acidiphilium, Amycolatopsis, Arthrobacter, } \\
\text { Azospirillum, Burkholderia, Caulobacter, Klebsiella, } \\
\text { Pirellula, Planctomyces, Polaromonas, } \\
\text { Pseudomonas, Rhodopirellula, Rubrobacter, } \\
\text { Saccharopolyspora, Spirosoma, Streptosporangium, } \\
\text { Xanthobacter }\end{array}$ & $\begin{array}{l}\text { Agrobacterium, Azorhizobiuı } \\
\text { Azospirillum, Burkholderia, } \\
\text { Cupriavidus, Geodermatoph } \\
\text { Klebsiella, Mesorhizobium, F } \\
\text { Polaromonas, Pseudomor } \\
\text { Rhodococcus, Rhodopirellui } \\
\text { Saccharopolyspora, Spiroso } \\
\text { Streptomyces, Streptosporar } \\
\text { Xanthomonas, }\end{array}$ \\
\hline
\end{tabular}




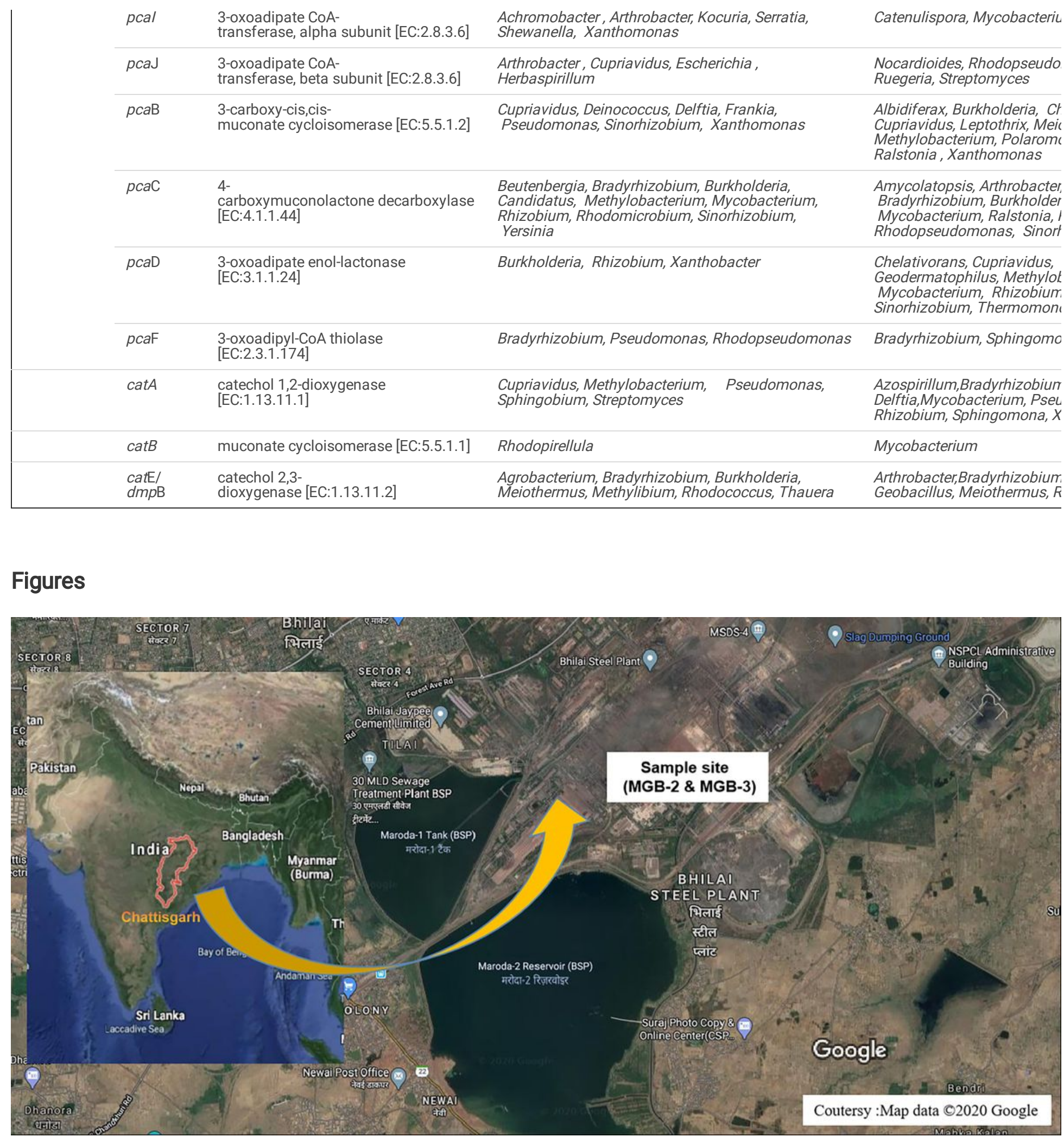

\section{Figure 1}

Map illustrating the sampling location of soil samples MGB-2 and MGB-3 collected from a polluted site near Bhilai steel plant, Chattisgarh (India). Note: The designations employed and the presentation of the material on this map do not imply the expression of any opinion whatsoever on the part of Research Square concerning the legal status of any country, territory, city or area or of its authorities, or concerning the delimitation of its frontiers or boundaries. This map has been provided by the authors. 


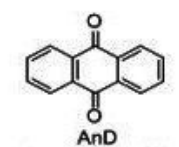

AnD
$(0.47 \% ; 1.88 \%)$

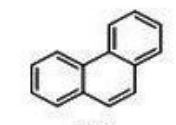

(2.66\%; $5.46 \%$ )
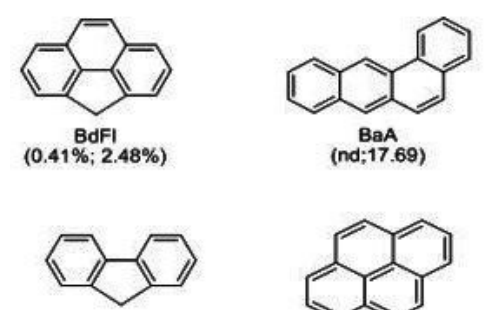

$\mathrm{F}$
$(15.89 \% ; n d)$
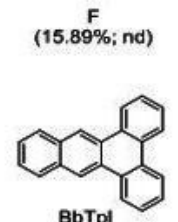

(0.97\%;0.05\%)

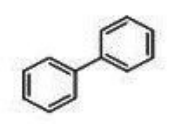

Bph
(tr; tr)

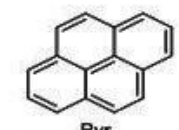

(nd; $18.7 \%$ )

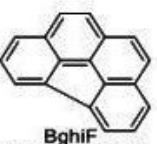

Bghif
$(0.84 \% ; 2.48 \%)$

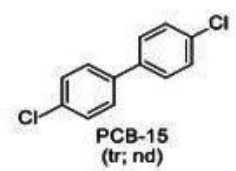

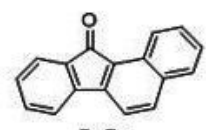

BaFo
$0.75 \% ; 2.71 \%)$

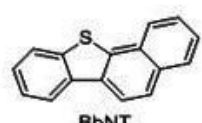

(1.5\%; $4.34 \%)$

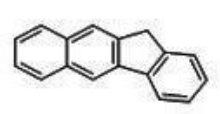

$\mathrm{BbFI}$

$(0.96 \% ; 6.1 \%)$
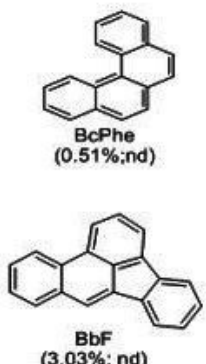

(3.03\%; nd)

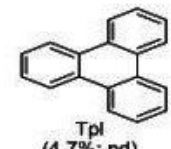

(4.7\%; nd)

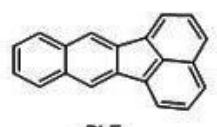

$\mathrm{BkF}$
$11.29 \% ; n d$
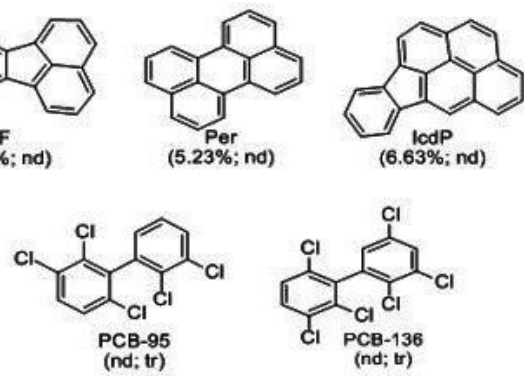

"nd indicates not detected in the given sample Hitr indicates detected in traces

Figure 2

Structure and relative abundance of the PAH and PCB identified. PAH found in MGB-2 \& MGB-3 were 9,10-Anthracenedione (AnD), 11H-Benzo[a]fluoren-11-one (BaFo), 11H-Benzo[b]fluorene (BbFI), Benzo[def]fluorene (BbFI), Benzo[b]fluoranthene (BbF), Benzo[b]naphtho[2,1-d]thiophene (BbNT), Benzo[b]triphenylene (BbTPI), Benzo[c]phenanthrene (BcPhe), Benzo[ghi]fluoranthene (BghiF), Benzo[k]fluoranthene (BkF), Fluorene (F), Indeno[1,2,3-cd] pyrene (IcdP), Perylene (Per), Phenanthrene (Phe), Pyrene (Pyr) and Triphenylene (Tpl) and are classified based on the numbers of aromatic rings 2, 3, 4, 5 and 6 membered rings. Bph, PCB-15, PCB-95 and PCB-136 represents biphenyl, 1,1'-biphenyl, 4,4'-dichloro, biphenyl, 1,1'-biphenyl 2,2',3','5,6 pentachloro and 1,1'-biphenyl 2,2',3,3',6,6' hexachloro respectively.

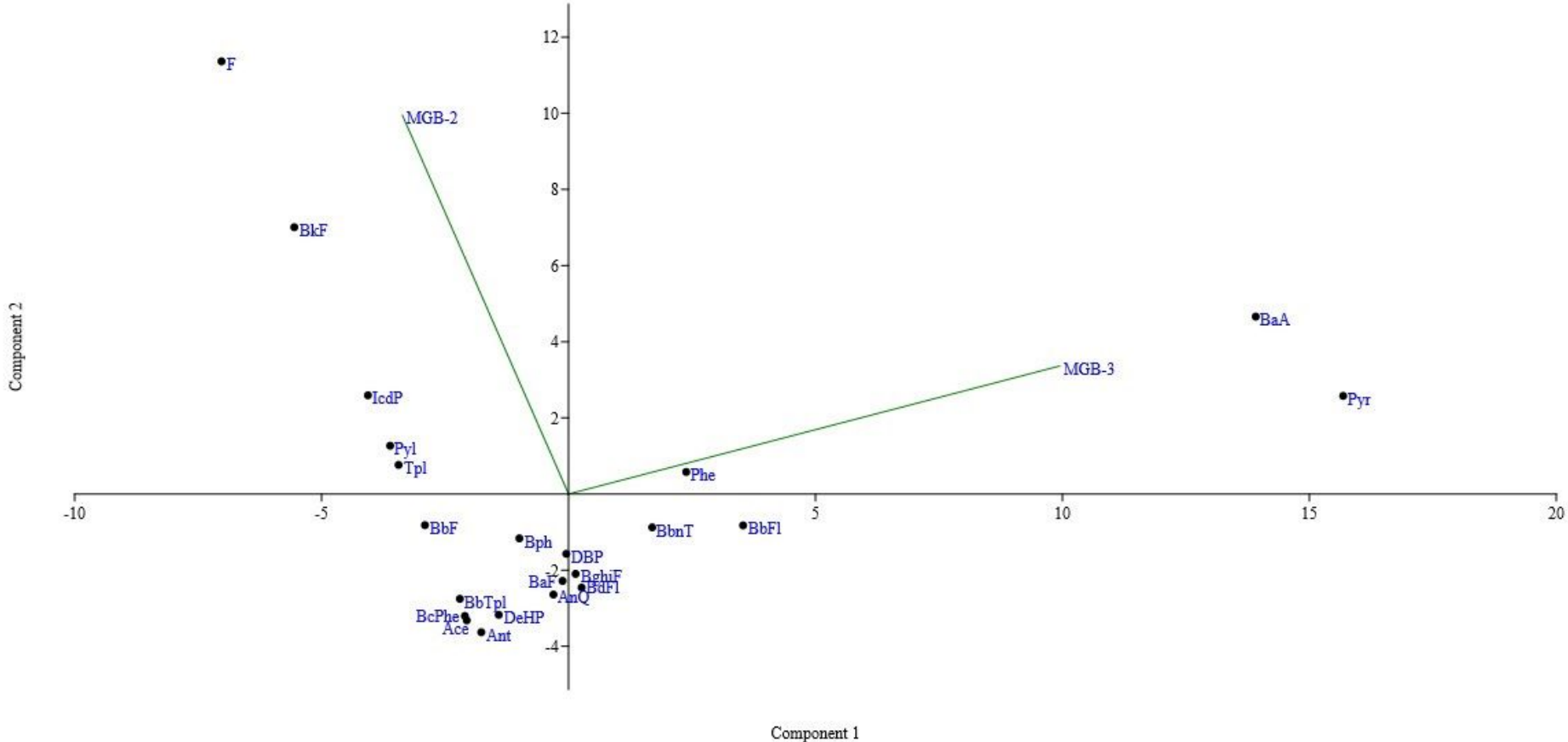


Figure 3

PCoA plot depicting relative abundance of PAH in MGB-2 and MGB-3 using Bray-Curtis matrix

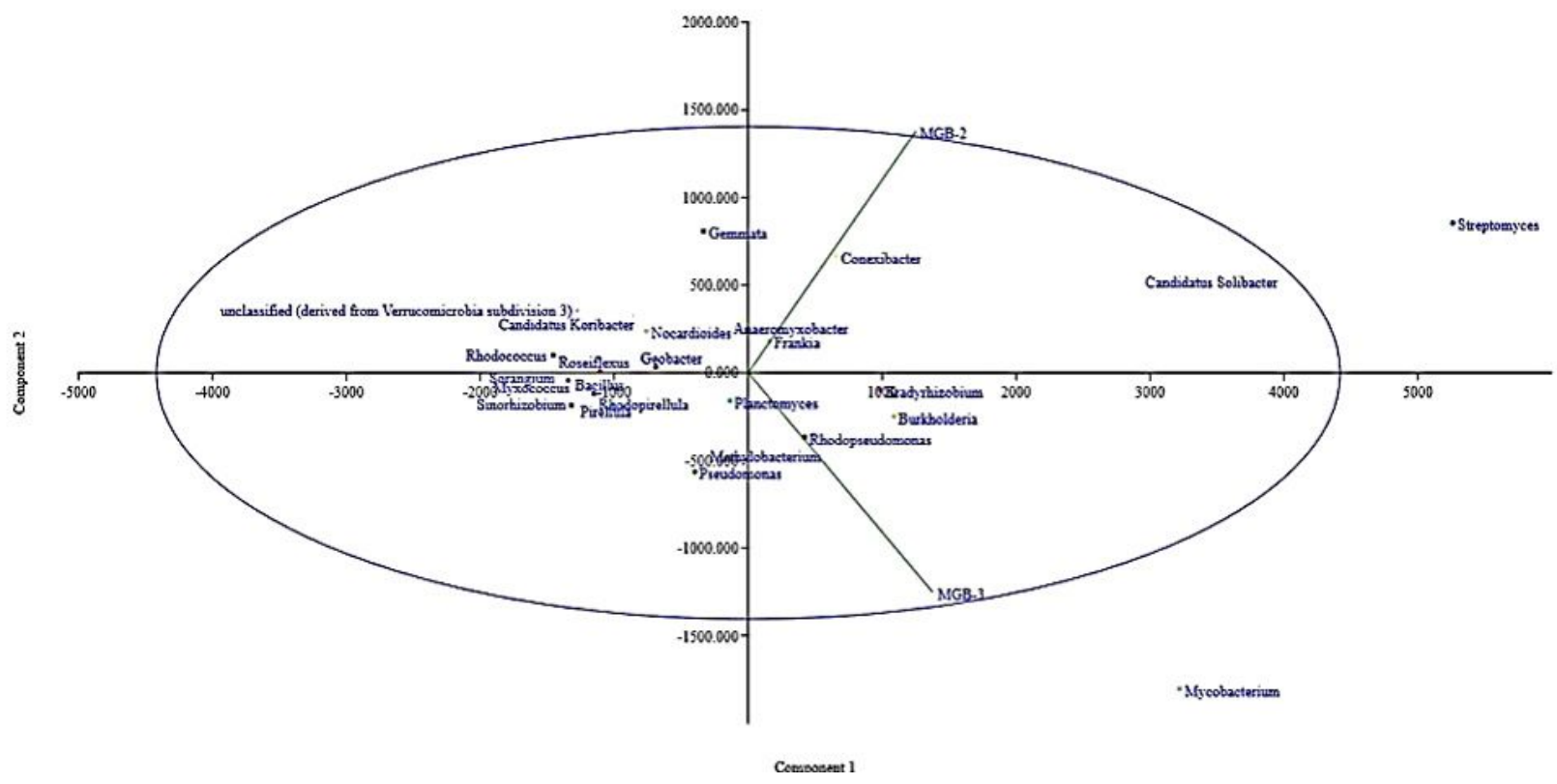

\section{Figure 4}

PCA plot depicting taxonomic analysis beta diversity of MGB-2 and MGB-3 on Bary -Curtis dissimilarity
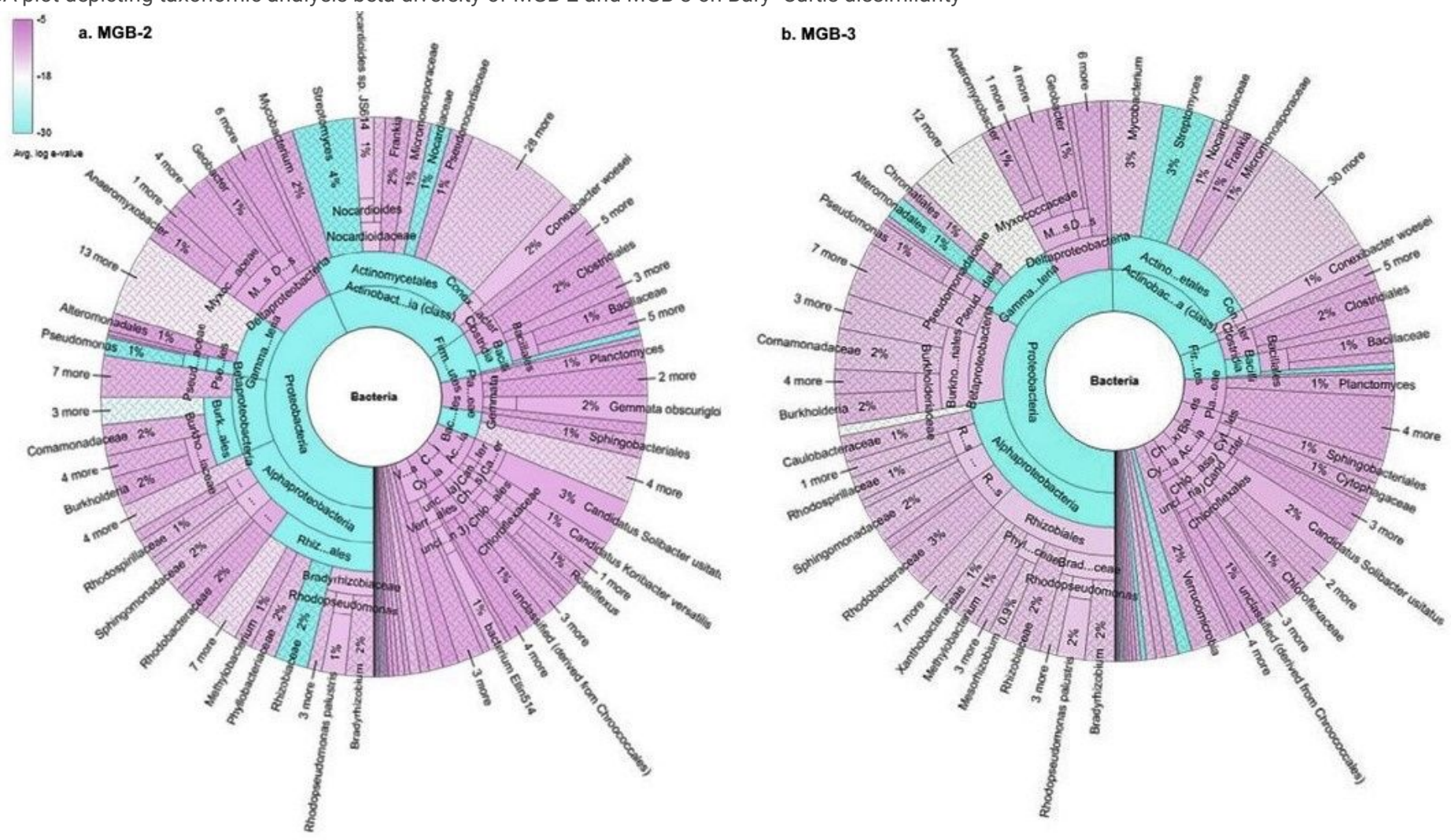

\section{Figure 5}

Krona plot demonstrated the relative abundance of taxa of bacteria across phylum to genus level hierarchy of a. MGB-2; b. MGB-3 
a.

00680 Methane metabolism [PATH:ko00680] 00785 Lipoic acid metabolism [PATH:k000785] 00020 Citrate cycle (TCA cycle) [PATH:ko00020] 00710 Carbon fixation in photosynthetic organisms [PATH:ko00710] 00620 Pyruvate metabolism [PATH:ko00620] 00983 Drug metabolism - other enzymes [PATH:k000983] 00250 Alanine, aspartate and glutamate metabolism [PATH:ko00250]" 00380 Tryptophan metabolism [PATH:ko00380] 00790 Folate biosynthesis [PATH:ko00790] "00280 Valine, leucine and isoleucine degradation [PATH:ko00280]" 00906 Carotenoid biosynthesis [PATH:ko00906] 00627 Aminobenzoate degradation [PATH:ko00627] 00053 Ascorbate and aldarate metabolism [PATH:ko00053] 00740 Riboflavin metabolism [PATH:ko00740] 를 00909 Sesquiterpenoid and triterpenoid biosynthesis [PATH:ko00909] 00450 Selenocompound metabolism [PATH:ko00450] 00071 Fatty acid metabolism [PATH:ko00071] 00310 Lysine degradation [PATH:ko00310] 00362 Benzoate degradation [PATH:ko00362]

$\square$ MGB2 MGB3

b.
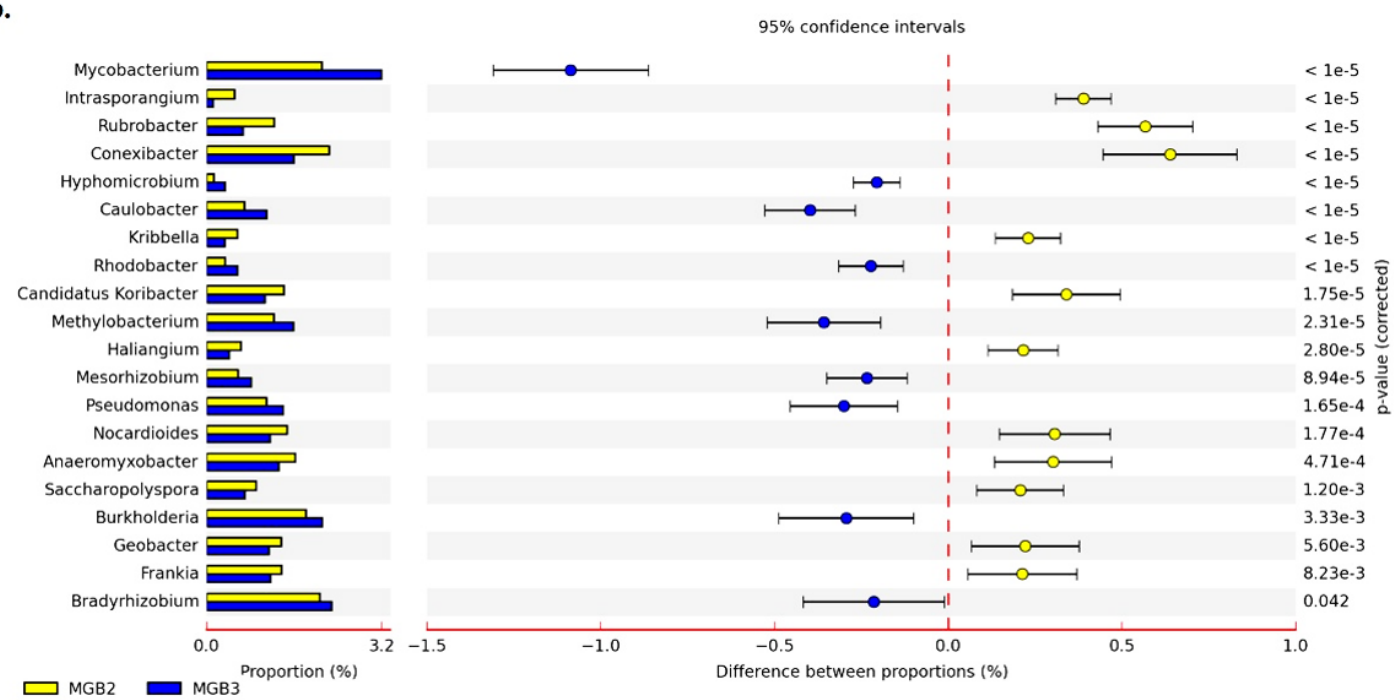

\section{Figure 6}

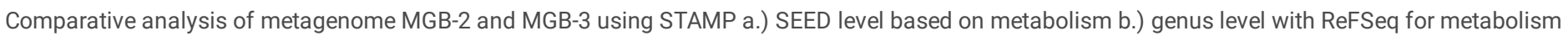


a.

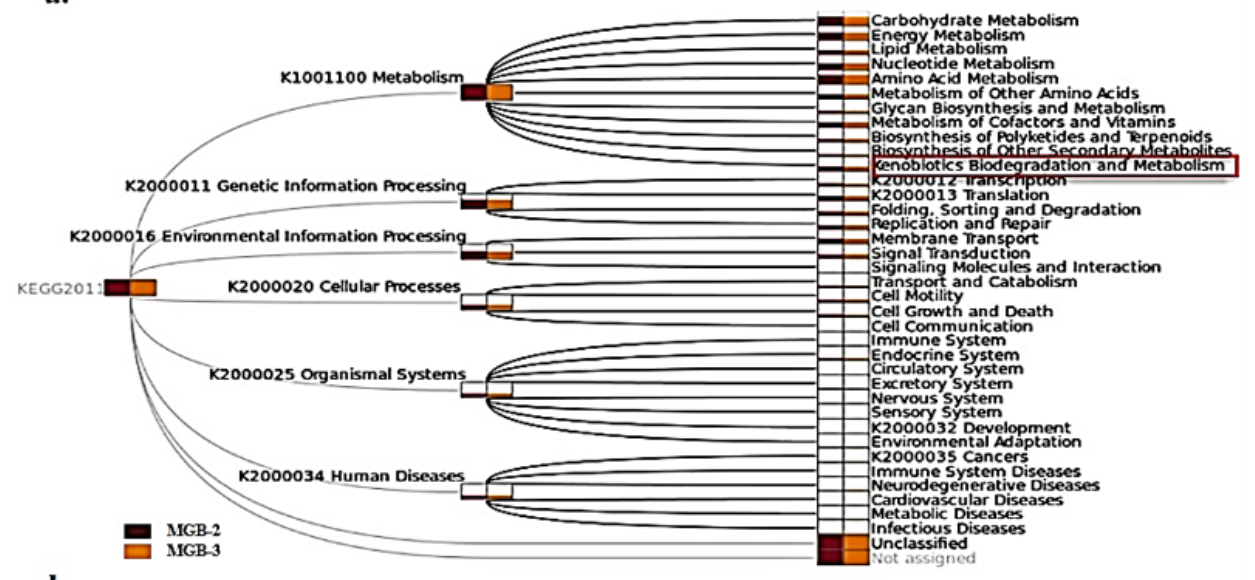

b.

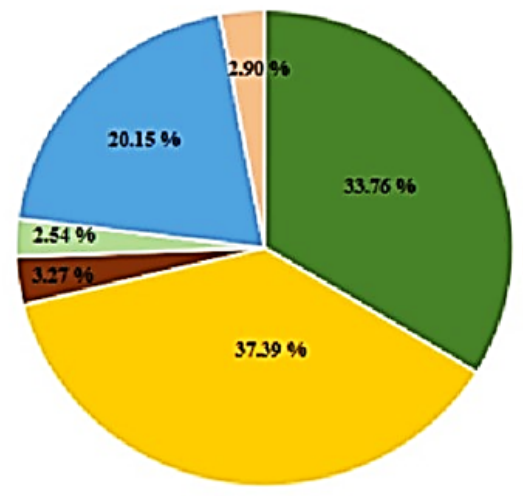

MGB-2

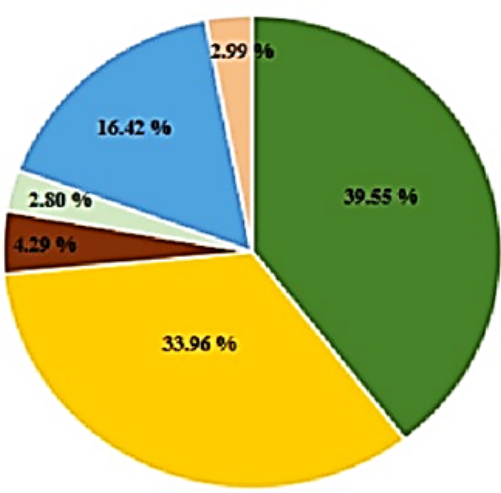

MGB-3

- Chorocyclohexame and chlorobenzene degradation [PATH:k000361]

- Benzoate degradation [PATH:ko00362]

- Dioxin degradation [PATH:ko00621]

= Polycyclic aromatic hydrocarbon degradation [PATH:ko00624]

- Aminobenzoate de gradation [PATH:ko00627]

- Miscellaneous

\section{Figure 7}

The SEED subsystem analysis in MG-RAST assigned reads in MGB-2 and MGB-3 based on various a.) functions b.) Xenobiotic biodegradation pathways 


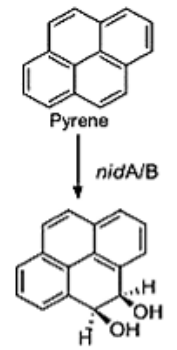

Pyrene cis-4,5-dihydrodiol

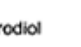

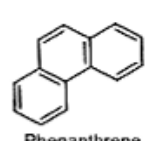

Phenanthrene
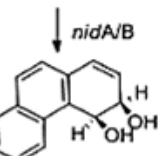

phenanthrene cis-3,4-dihydrodiol
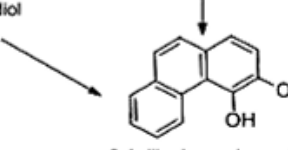

3.4-dihydroxy phenanthrene

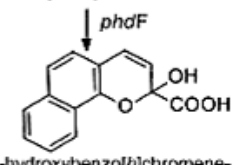

2-hydroxybenzo
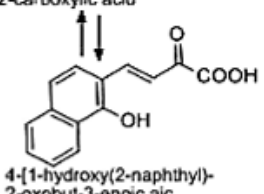

2-oxobut-3-onoic aic

phdG !

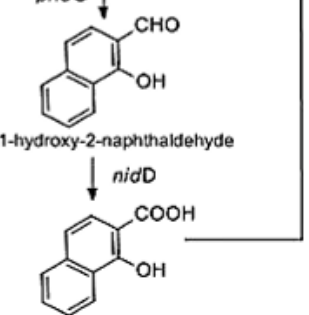

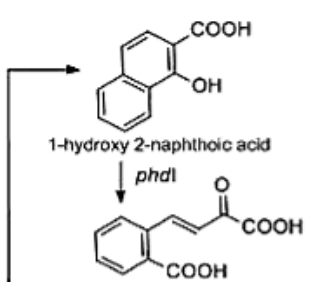

2'-carboxybenzalpyurvic acid

$\downarrow$ phas

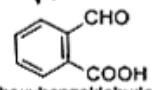

2-carboxybenzaldehyde

$\mid$ nidD

$\overbrace{\mathrm{COOH}}^{\mathrm{COOH}}$

o-phthalic acld

$\downarrow$ phtAa/Ab/Ac/Ad

COOH

pthatic acid cis-3,4-dinydrodiol

oht $\mathrm{B}$

COOH

$\mathrm{H}$

3,4, dihydroxypthalic acid

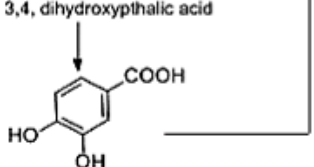

protocatechuic acid

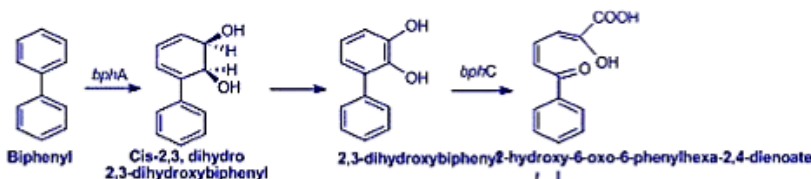
3-dihydroxybiphenyl HO Done

-ditydroxybiphony2-hydroxy-6-oxo-6-phenythexa-2,4-dienoate tpto
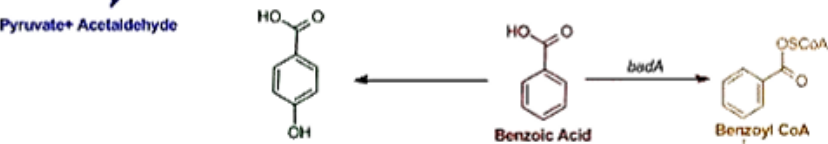

$\mathrm{OH}$ HOH

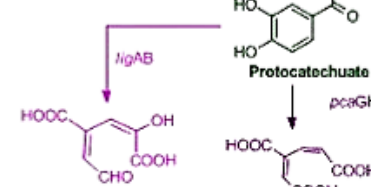

2-hydroxy-4-carbory
muconatesemiaberyde 3-carbaxy-cis.tis-muconate

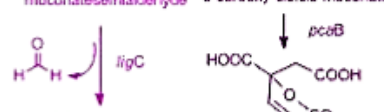

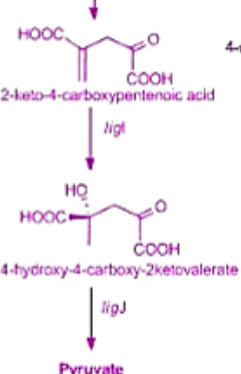

Berzoic Acid BensC bad DEFG OSCOM

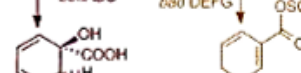

teno<smiles>[13CH3]</smiles>

cydotex.15-diere.1.

cartioxylicon

$\underbrace{\text { OSCOA }}_{0}$

cats

$\overbrace{\mathrm{COOH}}^{\mathrm{COOH}}$

Cyclohex-1-ene-t-carboxyl-Co:

book oscoA

O

2-Hydroxy cyclobexane.

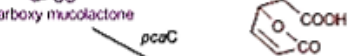

vucclaction

$\rightarrow \operatorname{corc}$

$\widehat{\mathrm{COOH}}$

ioco

oxoodpase enol- loctione

$\mathrm{C}_{\mathrm{COOH}}^{\mathrm{COOH}}$

3. Hydroxy gimely COA

i

7
$5 \mathrm{COCH}$ Dag H os COA

Figure 8

Reconstruction of complete Biphenyl/ PCB and PAH degradation pathways based on annotated genes identified. Blue, biphenyl degradation; red, benzoate degradation via catechol; pink, benzoate degradation via protocatechuate; orange, benzoate degradation via benzoyl CoA degradation; Black, PAH (Pyrene and Phenanthrene) degradation enter central pathway via protocatechauate intermediate 


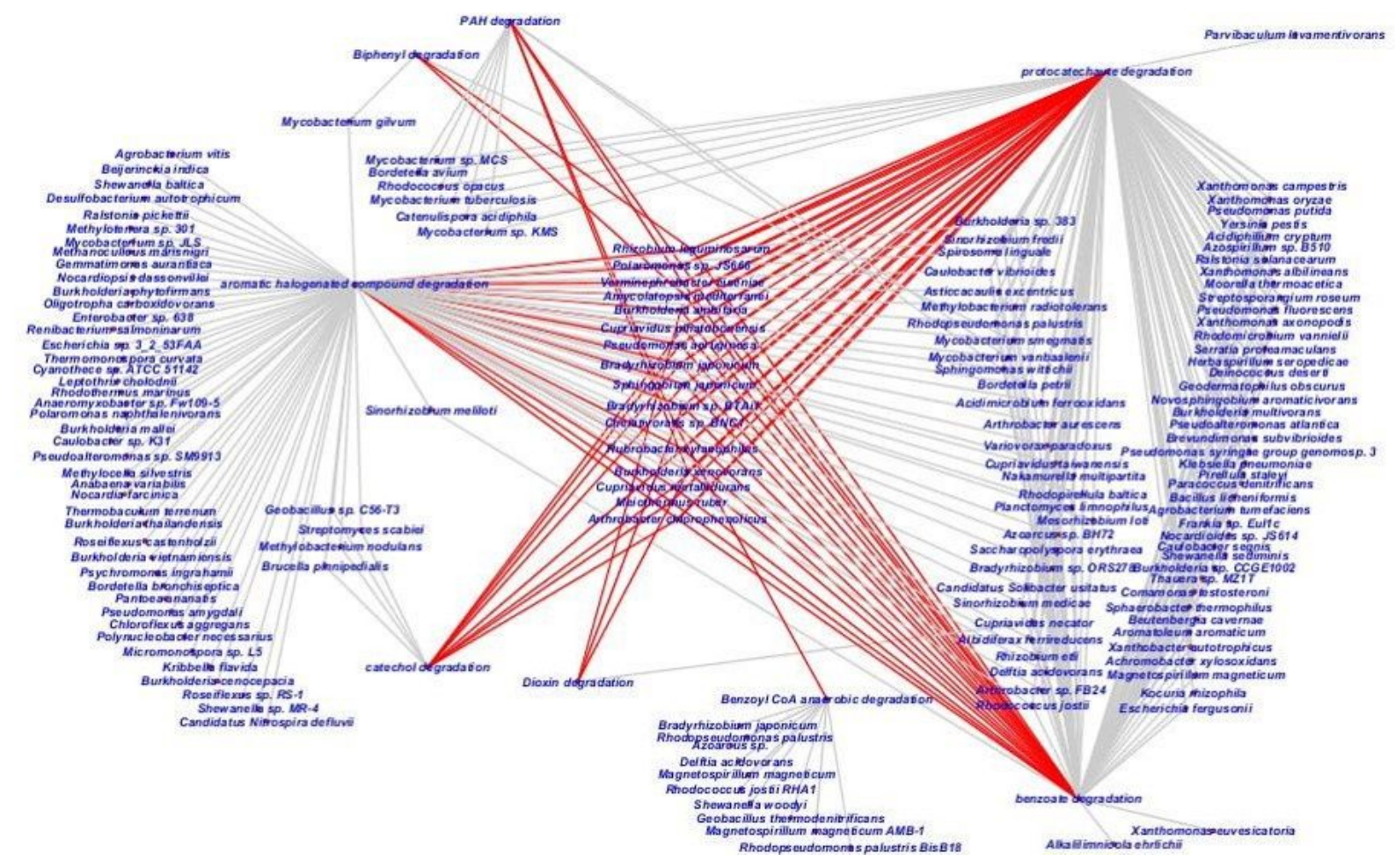

Figure 9

Cytoscape-based networking depicted interrelationship of key biodegrader in $\mathrm{PAH}$, biphenyl, dioxin, halogenated, catechol and protocatechol pathways in MGB-2. Key biodegrader presented in the middle and the interrelated pathways are given in red lines

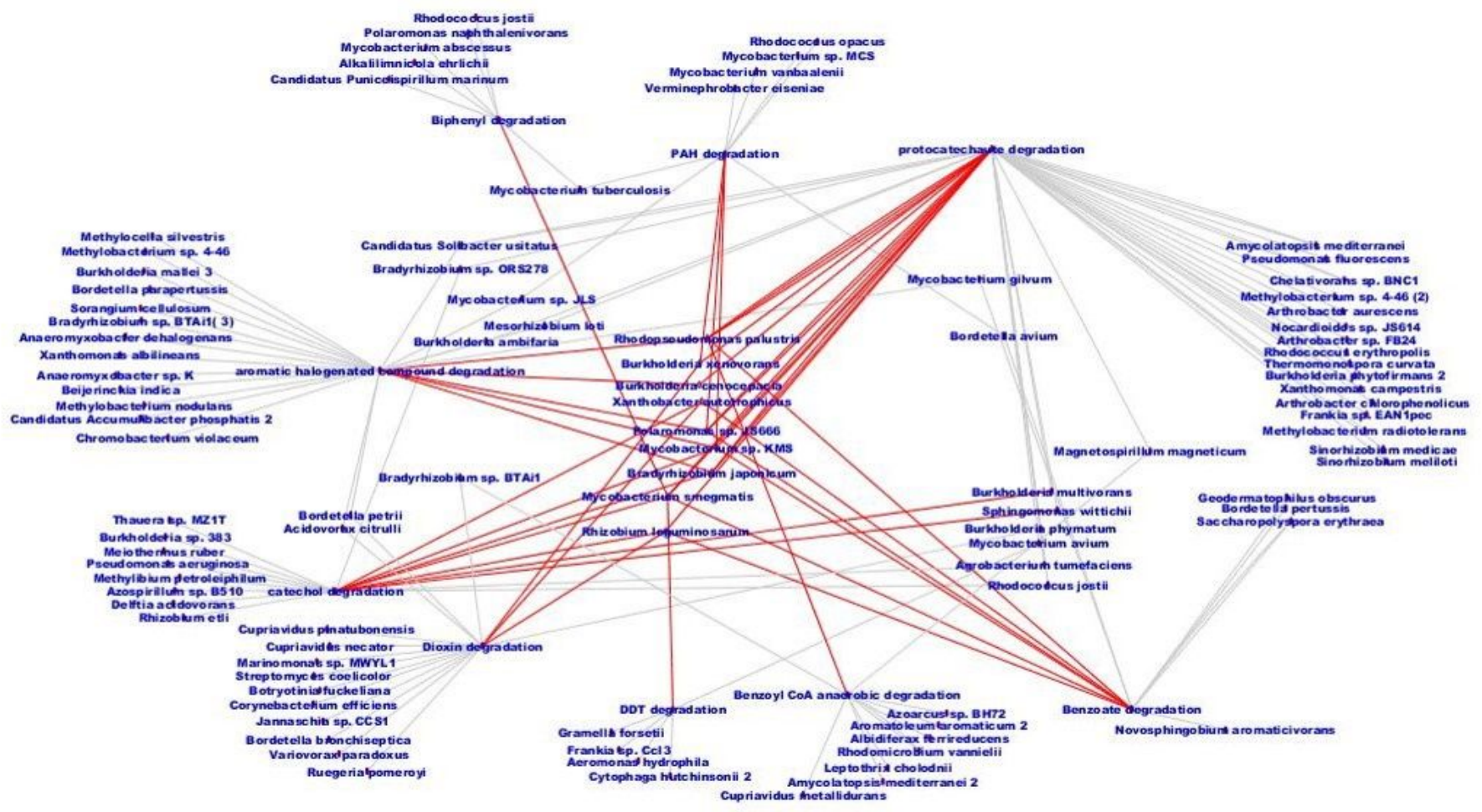

Figure 10

Cytoscape-based networking depicted interrelationship of key biodegrader in $\mathrm{PAH}$, biphenyl, dioxin, halogenated, catechol and protocatechol pathways in MGB-3. Key biodegrader presented in the middle and the interrelated pathways are given in red lines 
This is a list of supplementary files associated with this preprint. Click to download.

- supplementaryData.docx

Page 26/26 